\title{
Frasnian carbonate shoals and sequence stratigraphy of the Upper Devonian series from the southern Cantabrian Mountains, northern Spain
}

\author{
G. B. S. van Loevezijn ${ }^{(1)}$ and J. G. M. Raven ${ }^{(2)}$ \\ (1) Author for correspondence: Jan Sluijtersstraat 7, 3443 HP Woerden, \\ manipemieres@zonnet.nl \\ (2) Naturalis Biodiversity Center, Leiden, The Netherlands \\ han.raven@naturalis.nl
}

\begin{abstract}
The sequence stratigraphical framework of the Frasnian Nocedo Formation consists of two third-order sequences organised in the Gordón Member and the Millar Member in which three limestone intervals occur: the Molino Limestone at the top of the Gordón Member, the Varga Limestone at the base of the Millar Member (herein proposed as new unit to differentiate it from the Molino Limestone), and the Crémenes Limestone at the top of the Millar Member. The Molino Limestone has been studied in eighteen sections along a $70 \mathrm{~km}$ eastwest transect in the southern part of the Cantabrian Mountains. The limestone represents a skeletal carbonate shoal belt in a mixed siliciclastic-carbonate environment, located between the land area of the Asturian geanticline and the deeper distal, predominantly siliciclastic shelf. The Molino Limestone consists of three facies types representing a back shoal, shoal, and fore shoal. The Molino Limestone was deposited during the late Highstand Systems Tract of the lower sequence. In the proposed depositional model carbonate deposition was governed by currents controlled by relative sea-level. Effective lateral transport of siliciclastics on the shelf occurred during times when the water depth was sufficient for a current system to be established. As the water depth decreased siliciclastic sedimentation reduced and carbonates increasingly took over.
\end{abstract}

Keywords: Cantabrian Mountains, carbonate shoals, facies, Frasnian, sequence stratigraphy.

\section{Bancos carbonáticos frasnienses de la vertiente sur de la Cordillera Cantábrica, Norte de España}

\author{
RESUMEN
}

La serie estratigráfica frasniense de la Formación Nocedo está constituida por dos secuencias de tercer orden organizadas en el Miembro Gordón y el Miembro Millar, en las cuales aparecen tres intervalos calizos: las Calizas del Molino en la parte superior del Miembre Gordón, las Calizas de Varga en la base del Miembro Millar (aquí propuesto como una nueva unidad a diferenciar de las Calizas del Molino), y las Calizas de Crémenes en el techo del Miembro Millar. Las Calizas del Molino se han estudiado en dieciocho secciones a lo largo de un perfil este-oeste de $70 \mathrm{~km}$ en la parte sur de las Montañas Cantábricas. La caliza representa una barra costera de carbonato esqueletal en un ambiente mixto siliciclástico y carbonatado, localizado entre la parte continental del geoanticlinal Asturiano y la parte distal más profunda de plataforma predominantemente siliciclástica. Las Calizas del Molino consisten en tres tipos de facies que rapresentan back shoal, shoal y fore shoal. Las Calizas del Molino se depositaron durante el Highstands Systems Tract tardío de la secuencia inferior. En el modelo deposicional propuesto, la deposición de carbonato estaba gobernada por corrientes controladas por el nivel relativo del mar. El transporte lateral efectivo de siliciclastos sobre la plataforma tuvo lugar durante tiempos en los que la profundidad del agua era suficiente para que se estableciese un sistema de corrientes. Conforme decreció la profundidad del agua, la sedimentación siliciclástica se redujo y los carbonatos la fueron reemplazando progresivamente.

Palabras clave: bancos carbonáticos, Cordillera Cantábrica, estratigrafía secuencial, facies, Frasniense. 
van Loevezijn, G.B.S. and Raven, J.G.M., 2017. Frasnian carbonate shoals and sequence... Boletín Geológico y Minero, 128 (4): $931-961$

\author{
VERSIÓN ABREVIADA EN CASTELLANO
}

\title{
Introducción
}

Los bancos carbonáticos frasnienses de las Calizas del Molino, que afloran en el Sur de las Montañas Cantábricas, contienen diversas litofacies que varían de mudstones negros bituminosos a grainstones con cantidades variables de bioclastos. Los bancos carbonáticos se estudiaron en dieciocho columnas estratigráficas: diez en el sinclinal de Alba, cuatro en la unidad Peña Corada, dos en el sinclinal de Aguasalio y dos en el sinclinal de Pedroso (Fig. 1). El objetivo de este estudio incluye describir la estructura de las facies mediante la estratigrafía secuencial así como la elaboración de los modelos deposicionales y paleogeográficos de los bancos carbonáticos frasnienses.

\section{Estratigrafía del Devónico Superior}

Desde el punto de vista palaeogeografico se distinguen tres áreas en la Zona Cantábrica (Fig.1), el geoanticlinal Asturiano, las facies del área Astur-Leonesa y las facies del área Palentina. El geoanticlinal Asturiano de van Adrichem Boogaert (1962) o Bloque Cantábrico, según Radig (1962), que se caracteriza por la casi total ausencia de depósitos del Silúrico y Devónico y se localiza actualmente en Este y Norte de la zona de estudio, actuó como el área fuente de los materiales devónicos. Las facies del área Astur-Leonesa (Brouwer, 1962) están constituidas fundamentalmente por sedimentos gruesos con abundante fauna bentónica. Las facies del área Palentina (Brouwer, 1962) se caracterizan como depósitos pelágicos con escasos detríticos (Aramburu et al., 2004). La zona de estudio se encuadra dentro de las facies del área Astur-Leonesa (Fig. 1). Durante el Devónico superior los productos de erosión de las partes internas de la Cuenca Astur-Leonesa y el geoanticlinal Asturiano se dispusieron en forma de cuñas clásticas en la parte más externa de la Cuenca (Fig. 2). Estas cuñas se organizaron en tres formaciones: la Formación Nocedo del Frasniense, la Formación Fueyo del Fameniense y la Formación Ermita de edad Fameniense tardío - Turnasiense temprano (Comte, 1959; Aramburu et al., 2004). La Formación Nocedo se divide en dos: el Miembro Gordón es el inferior y el Millar el superior (Loevezijn, 1983). Cada uno contiene una secuencia siliciclástica granocreciente y una unidad de calizas suprayacente. Las calizas del miembro Gordón representan un bajío crinoidal y en el Miembro Millar biostromas de corales y estromatopóridos. Esta última unidad, la Caliza de Crémenes, está restringida a la parte oriental de la unidad de Peña Corada y al sinclinal de Aguasalio (Loevezijn et al., 1986; García Alcalde, 2012) (Fig. 6). La unidad caliza inferior, que se corresponde con la unidad Calizas del Molino de García-López \& Sanz López (2002), aparece intercalada con las areniscas costeras de la parte superior del miembro Gordón (Fig. 4). Esta tiene una amplia distribución geográfica y es el objeto de este estudio.

\section{Estratigrafía secuencial}

Se han identificado tres límites entre las secuencias de edad Frasniense (Fig. 7). El primero está situado en la base de la Formación Nocedo, el segundo es una superficie neta en la base del Miembro Millar (Fig. 8), el tercer límite es un contacto erosivo neto con una gradación de facies que varía desde areniscas con estratificación cruzada depositadas en la parte superior de la costa (Miembro de Millar, Frasniense) a lutitas de alta mar (Formación Fueyo, Fameniense, Loevezijn 1986). Dentro de cada una de las secuencias se pueden reconocer tres etapas: profundización, relleno progradacional y sin sedimentación detrítica. La etapa de profundización se correlaciona con el Transgressive Systems Tract (TST) de Van Wagoner et al. (1988) y Catuneanu et al. (2011). La etapa de relleno progradacional se correlaciona con el Highstand Systems Tract (HST) de Van Wagoner et al. (1988) y Catuneanu et al. (2011), y la etapa final se correlaciona con el HST tardío, y representa una fase dominada por la sedimentación de carbonatos, que se producía cuando el nivel relativo del mar subía a tasas cada vez más bajas.

\section{Calizas del Molino}

Los carbonatos son ricos en conodontos, que han sido estudiadas por muchos autores (Raven, 1983; GarcíaLópez, 1987; García-López y Sanz-López, 2002, entre otros). Se han reconocido las siguientes zonas de conodontos (García-López y Sanz-López, 2002): Zona Superior de Mesotaxis falsiovalis, Zona de Palmatolepis transitans, Zona de Palmatolepis punctata y Zona Inferior de Palmatolepis hassi. Además de conodontos, las calizas también son ricas en otros tipos de fauna microscópica y macroscópica. Basándose en características litológicas y en el contenido faunístico, las Calizas del Molino pueden agruparse en tres tipos principales de 
van Loevezijn, G.B.S. and Raven, J.G.M., 2017. Frasnian carbonate shoals and sequence... Boletín Geológico y Minero, 128 (4): $931-961$

facies, FT1 a 3, depositadas dentro de un ambiente de bancos mixtos de arenas siliciclásticas y carbonáticas: back shoal (FT1) con un subtipo de wackestone-packstone lutítico (FT1a) y un subtipo de mudstone-wackestone (FT1b), un banco (FT2) con subtipo de grainstone bioclástico de grano fino (FT2a), un subtipo de grainstone arenoso (FT2b) y un subtipo de grainstone bioclastico de grano grueso (FT2c), y foreshoal (FT3) con areniscas (Figuras 9, 3). Dentro de las Calizas del Molino, se pueden reconocer secuencias de facies o ciclos de pequeña escala (Fig. 10): back shoal, shoal core, shoal core-fringe, y shoal fringe. Estos ciclos reflejan cambios relativos en el nivel del mar a pequeña escala dentro del ciclo de tercer orden del miembro Gordón: ciclos a pequeña escala 'a' $y$ ' $b$ ' (Fig. 11). El ciclo 'a' está presente en todas las secciones Molino (Fig. 12). Internamente, el ciclo muestra un incremento creciente de la energía de sedimentación pasando de depósitos limosos matriz soportados (FT1) a depósitos arenosos y gruesos (FT2b, FT2c). El ciclo en pequeña escala ' $b$ ' ocurre sólo en parte del sinclinal de Alba (secciones $\mathrm{H}$ y O). El ciclo es de tipo granocreciente con grainstones de grano fino (FT2a) y arenosos (FT2b) en la base y packstones y grainstones bioclásticos de grano grueso en la parte superior (FT2c), lo que representa un aumento de la energía.

\section{Discusión y conclusiones}

Durante la última parte del HST las secciones estudiadas se localizaron en una parte poco profunda de la plataforma con corrientes lo suficientemente fuertes como para (re)distribuir los componentes siliciclástcos (Fig. 13). Debido a la reducción del espacio de acomodación, la distribución de los granos detríticos silíceos se restringió a las partes distales más profundas de la plataforma, donde la profundidad del agua era suficiente para el desarrollo de un sistema de corrientes paralelas a la costa. La producción tardía de carbonatos de HST redujo, aún más, el espacio de acomodación y detuvo el transporte de detríticos paralelo a la costa, lo que condujo al dominio de la sedimentación carbonática. El banco de calizas principal se desarrolló donde la subsidencia fue menor (Figura 14A). El patrón de sedimentación de las Calizas del Molino muestra un desplazamiento lateral del depocentro hacia el suroeste (Figura 14B). La ausencia de superficies profundas de erosión y discontinuidades bien desarrolladas en las superficies de contacto de los ciclos de pequeña escala indica una pendiente de deposición muy suave con cambios de nivel del mar de baja amplitud donde los cinturones de facies se mueven a favor o en contra de la pendiente de una plataforma suavemente inclinada. Estas características son típicas de un sistema de rampa en condiciones climáticas de tipo invernadero (greenhouse) (Read, 1998, Zeller et al., 2015). El clima del Frasniense se caracteriza por intervalos muy calientes con pulsos de enfriamiento cortos durante el Frasniense terminal (Joachimsky et al., 2009). En un sistema mixto con una plataforma suavemente inclinada y condiciones tropicales, es improbable que la producción de carbonato se detenga completamente (Yancey, 1991; Buescher, 2003; Zeller et al., 2015). El modelo de sedimentación recíproca de Miall (2016) contempla sistemas con sedimentación alternante, en los que hay una separación clara entre los ciclos carbonáticos y los siliciclásticos. En el área de estudio, sin embargo, tanto los sistemas deposicionales siliciclásticos y carbonáticos coexistieron con variaciones en el aporte relativo de cada uno de ellos. Zeller et al. (2015) desarrollaron un modelo para ambientes sedimentarios de naturaleza mixta en plataformas con pendientes suavemente inclinados (Tabla 1). Durante las últimas etapas la distribución de los componentes siliciclásticos en la plataforma se redujo sustancialmente debido a la falta de aportes desde el área fuente, que se encontraba inundada en gran parte. Además, el aumento de la producción de carbonatos redujo aún más el espacio de acomodación y, por lo tanto, cerró el transporte siliciclástico en la plataforma, lo que dio lugar al dominio de la producción y retrabajamiento de los carbonatos (Calizas del Molino y de Crémenes).

\section{Introduction}

Although the bioclastic shoal deposits of the Molino Limestone have long been recognised, a systematic sedimentological analysis of these deposits is not yet available. Most studies have a palaeontological approach, dealing with the rich fossil content of the shoals, and contain a limited lithological description. In most cases only the very coarse grained, purple coloured bioclastic limestones are mentioned (Herbig and Buggish, 1984; García Alcalde et al., 1985; García-
López and Sanz López, 2002). The Frasnian shoal deposits in the Cantabrian Mountains contain a broad range of lithofacies types from dark bituminous mudstones to coarse bioclastic grainstones with a varying siliciclastic content. The objective of this study is to unravel the facies patterns of the Molino Limestone with a sequence stratigraphic approach, to construct a depositional model, and to interpret the palaeogeography. The Molino Limestone is compared with the other limestones in the Nocedo Formation, but these are not discussed in detail. 


\section{Methodology}

The present study is part of an investigation on the stratigraphy of the Devonian rocks in the southern Cantabrian Mountains which the authors carried out in the late 1970s and early 1980s as staff members of the former Department of Palaeontology and Stratigraphy, University of Leiden. During several field campaigns sections were logged and sampled, and palaeocurrent directions were measured. The measured sections were worked out in detail including recognition of facies types; simplified sections were combined into correlation panels, isopach maps were constructed and palaeocurrent directions com- pared. Rock samples were studied in the laboratory, including preparation and study of thin sections, and the extraction and study of conodonts which were used to control the correlations based on lithology. Additional field work was carried out in 2015.

The shoal deposits were studied in eighteen sections; ten in the Alba syncline, four in the Peña Corada unit, two in the Aguasalio syncline, and two in the Pedroso syncline (Fig. 1).

\section{Geological setting}

The Palaeozoic deposits of the Cantabrian Mountains

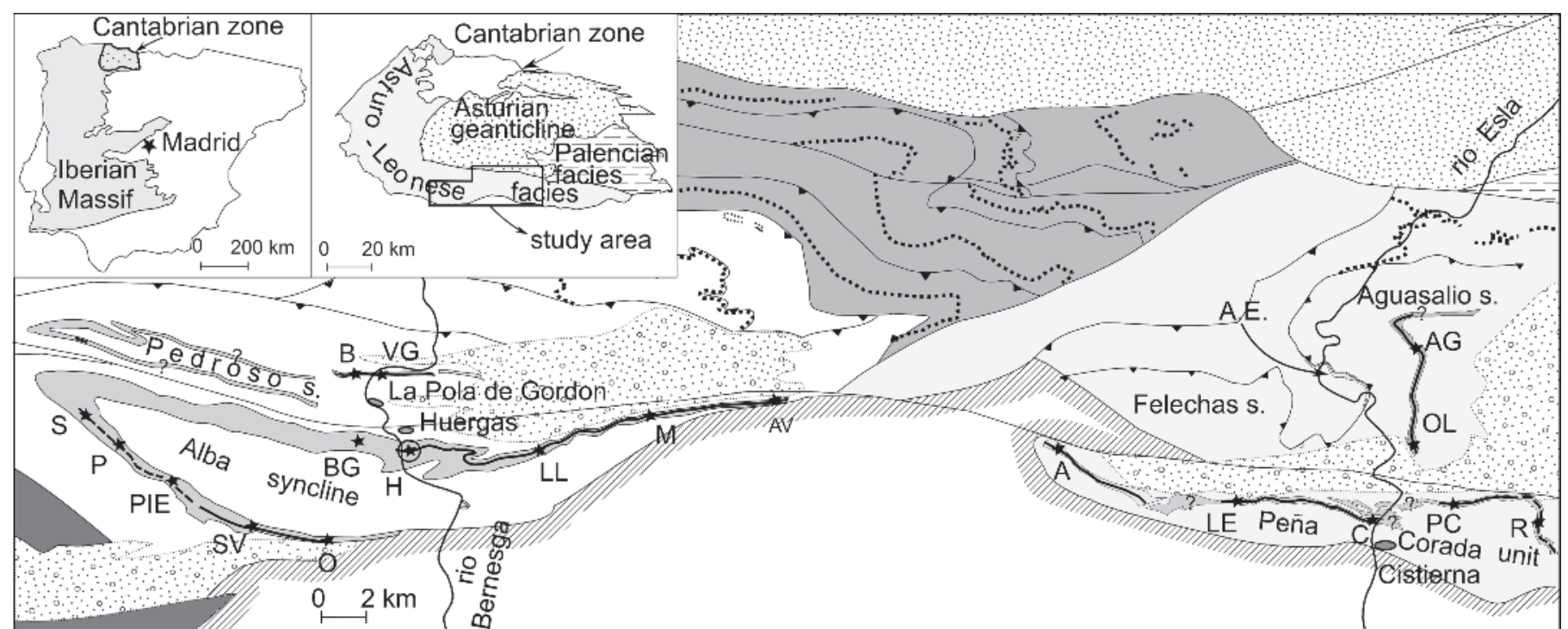

Somiedo Correcilla Unit

Sobia Bodoń Unit

Esla Unit

Fold and Nappe Province

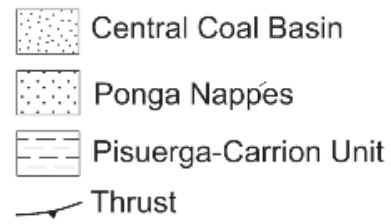

—Thrust

Figure 1. Study area with the tectono-stratigraphic subdivision (modified from Julivert (1971), Peréz Estaún et al. (1988), and Alonso et al. (2009), and the Upper Devonian with the Molino Limestone. Palaeogeographically the Central Coal Basin and the Ponga Nappe Unit are part of the Asturian geanticline; the Sobia-Bodón Unit, the Somiedo-Correcilla Unit and the Esla Unit are part of the Asturo-Leonese facies area. The Pisuerga-Carrión unit is part of the Palencian facies area.

A.E. = Autochthon of Esla nappe. Abbreviations for the sections; Bernesga area: $\mathrm{S}=$ Saguera, $\mathrm{P}=$ Portilla de Luna, PIE = Piedrasecha, SV = Santiago de las Villas, $\mathrm{O}=$ Olleros de Alba, BG = Barrios de Gordón, H = Huergas de Gordón, $\mathrm{LL}=\mathrm{Llombera}, \mathrm{M}=\mathrm{Matallana}$ de Torío, AV= Aviados, $B=$ Beberino, VG = Vega de Gordón; Esla area: $A=$ San Adrián, LE = La Ercina, C = Cistierna, PC = Peña Corada, R = Robledo, OL $=$ Santa Olaja de la Varga, $\mathrm{AG}=$ Aguasalio.

Figura 1. Área de estudio con la subdivisión tectono-estratigráfica (modificada de Julivert (1971), Peréz Estaún et al. (1988) y Alonso et al. (2009)I, y el Devónico Superior con las Calizas del Molino. Paleogeográficamente la Cuenca Central del Carbón y la Unidad Ponga Nappe forman parte del geoanticlinal asturiano; La Unidad Sobia-Bodón, la Unidad Somiedo-Correcilla y la Unidad Esla forman parte de la zona de facies Asturo-Leonesa. La unidad Pisuerga-Carrión forma parte de la zona de facies Palentina.

A.E. = Esla nappe. Abreviaturas para las secciones; Bernesga: $S=$ Saguera, $P=$ Portilla de Luna, PIE = Piedrasecha, SV $=$ Santiago de las Villas, $O=$ Olleros de Alba, $B G=$ Barrios de Gordón, $H=$ Huergas de Gordón, $L L=L l o m b e r a, M=M a t a l l a n a$ de Torío, AV $=A v i a d o s, B=$ Beberino, VG = Vega de Gordón; Esla área: $A=$ San Adrián, $L E=$ La Ercina, $C=$ Cistierna, $P C=$ Peña Corada, $R=R o b l e d o, O L=S a n t a$ Olaja de la Varga, $A G=$ Aguasalio. 
are part of the Cantabrian Zone; the northern thrust and fold belt of the Iberian Massif (Lotze, 1945; PérezEstaun et. al., 2004). The present geological setting is the result of nappe tectonics, which affected the Cantabrian Zone during the late Carboniferous. The Cantabrian zone is subdivided into several tectonostratigraphic regions or units (Julivert, 1971; Peréz Estaún et al., 1988; Alonso et al., 2009) (Fig. 1). The sections of the Alba syncline and the Pedroso syncline are located in the thrust complex of the Somiedo-Correcilla unit; the sections of the Peña Corada unit and the Aguasalio syncline are part of the thrust complex of the Esla unit. Palaeogeographically, three areas are distinguishable in the Cantabrian Zone (Fig.1), a geanticline and the areas covered by two facies. The Asturian geanticline of van Adrichem Boogaert (1962) or the Cantabrian Block of Radig (1962), located to the east and north of the study area in present day coordinates, is characterised by the almost complete absence of Silurian and Devonian deposits, and was the source area for the Devonian basin (Hofmann and Keller 2005). Based on the features of the non-metamorphic to slightly metamorphic Devonian succession, Brouwer (1962) distinguished two facies: an Asturo-Leonese facies characterised by coarse sediments with an abundant benthic fauna, and a Palencian facies characterised by scarce detrital material in which pelagic elements are dominant (Aramburu et al., 2004). The study area is part of the Asturo-Leonese facies area (Fig. 1).

There is still considerable discussion and disagreement about the provenance and the lateral displacement of the allochthonous complexes (Keller et al., 2008), and the significance, location and presentday identification of pre-Variscan features and palaeogeographical reconstructions (Keller et al., 2008; Fernández Martinez et al., 2010; Fernández et al., 2006; Nijman and Savage, 1991; Alonso et al., 1991). Given these facts, palaeogeographic pre-Variscan reconstructions will be treated with caution. However when constructing a depositional model some palaeogeographic assumptions have to be made.

\section{Upper Devonian stratigraphy}

The Devonian succession in the Cantabrian Mountains was deposited on an extensive stable shelf with a mixed sedimentation of carbonates and siliciclastics, fed from a continental landmass, the Asturian geanticline, located north of the study area (Loevezijn,1989; Keller et al., 2007; Fernandez Martinez et al., 2010). Due to tectonic movements during the Late Devonian the basin configuration changed, the depositional area shifted towards the distal parts of the shelf, whilst the inner part of the Asturo-Leonese shelf emerged and became a sediment-shedding area (Loevezijn, 1989; Keller et al., 2008). Rapid lateral changes in Upper Devonian facies patterns and thickness created a complex jigsaw of lithologies. The erosion products of the inner part of Asturo-Leonese basin and the Asturian geanticline formed three clastic wedges in the outermost part of the basin (Loevezijn, 1986).

These Upper Devonian deposits are organised into

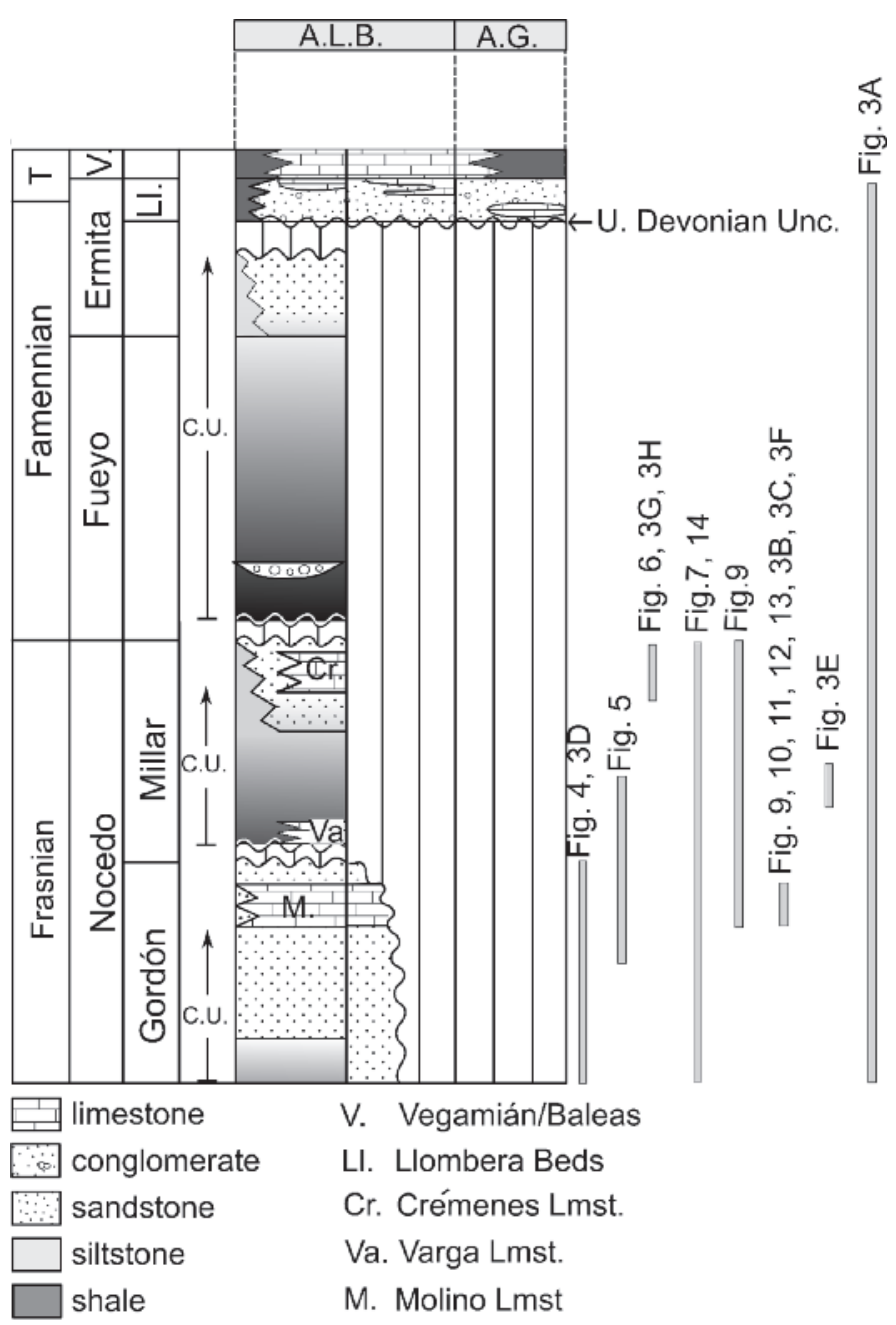

C.U. coarsening upward

Figure 2. Upper Devonian stratigraphy of the southern Cantabrian Mountains. A.L.B. = Asturo-Leonesian basin; A.G. = Asturian geanticline.

Figura 2. Estratigrafía del Devónico Superior de las Montañas Cantábricas meridionales. A.L.B. = Cuenca Asturo-Leonesiana; A.G. = Geoanticlinal asturiano. 
three formations: the Frasnian Nocedo Formation, the Fueyo Formation of early Famennian age and the Ermita Formation of late Famennian-earliest Tournaisian age (Comte, 1959; Aramburu et al., 2004). Later these formations were subdivided and new names were introduced. The Nocedo Formation was split into a lower Gordón Member and an upper Millar Member (Loevezijn, 1983), each containing a siliciclastic coarsening upward sequence overlain by a limestone unit: a crinoidal shoal unit in the top of the Gordón Member, the Molino Limestone, and a biostromal coral-stromatoporoid unit in the top of the Millar Member, the Crémenes Limestone (Fig. 2). The Molino Limestone is the subject of this study.

The Nocedo Formation is absent closer to the Asturian geanticline, where the Upper Devonian unconformity truncates Lower Devonian or Silurian deposits, whilst on the Asturian geanticline itself the Upper Devonian unconformity progressively truncates Silurian, Ordovician and Cambrian deposits. The boundary between the Nocedo and Fueyo Formations is located at the top of the coarsening upward sequence of the Millar Member (Loevezijn, 1983). As a consequence the overlying 20 to $25 \mathrm{~m}$ thick shale containing conglomerate beds form the basal part of the Fueyo Formation as advocated by Rodríguez Fernández et al. (1985) and Truyols et al. (1990) (García Alcalde et al., 2002). The upper part of the Fueyo Formation gradually changes upward from shales to sandy shales to the silty sandstones of the Ermita Formation. The Fueyo Formation and the lower part of the Ermita Formation form the third coarsening upward sequence, separated from the upper part of the Ermita Formation by the Upper Devonian unconformity. Keller et al. (2008) introduced the name Llombera Beds for this transgressive upper part of the formation with microconglomerates and coarse limestone intercalations (Fig. 2). In the southernmost part of the Alba syncline near Olleros de Alba (section O) the Llombera Beds are replaced by an alternation of dark shales and muddy limestones (Loevezijn, 1986; Sanz López et. al., 1998). The Ermita Formation is overlain by a condensed sequence of clastic limestones of the Baleas Formation or by black shales of the Vegamián Formation (Aramburu et al., 2004), which at least in part, are time equivalent (Raven, 1983; Sánchez de Posada et al., 2002).

\section{Frasnian limestone units}

Molino Limestone: The Molino Limestone of GarcíaLópez and Sanz López (2002) has an extensive geographical distribution and occurs from east to west in the structures of the Aguasalio unit, Peña Corada unit, the Alba syncline, and the Pedroso syncline (Fig. 1). Outside the study area the limestone also occurs in the Palomas, Quejo, and Saliencia synclines (Loevezijn, 1986). The up to $52 \mathrm{~m}$ thick succession is intercalated within the shoreface sandstones of the upper part of the Gordón Member. It is regarded as near-shore shoal belt deposit (Sanchez de la Torre, 1977; Loevezijn, 1986; Aramburu et al., 2004), and represents a non-reefal skeletal sandy carbonate body within a south facing, gently inclined, mixed carbonate-siliciclastic ramp. Figure 4 summarises the suc-

Figure 3. A) Llombera section (LL) showing the Portilla Formation (P), a sandy developed Gordón Member (G) with the Molino Limestone, the coarsening upward successions in the Millar Member (M), and the Fueyo to Ermita Formations, and the Upper Devonian Unconformity (UDU). B) Ichnofauna of the Skolithes facies in the sandy grainstones (FT2b) of the Molino Limestone, cycle 'a', Shoal Core-Fringe cycle type, Huergas section (H). C) Cross-bedded ferruginous sandy grainstones (FT2b) of the Molino Limestone, cycle 'a', Shoal Fringe cycle type. Arrow points to direction of top. Section Saguera (S). D) Beberino section showing the erosive bounding surface between the Portilla Formation (P) and the Gordón Member of the Nocedo Formation (G). E) Laminated siltstones and shales with sharp based, thin bedded sandstone. Arrow points to direction of top. Millar Member. Section Llombera (LL). F) Cross-bedded sandy limestones and calcareous sandstones (FT2b) of the Molino Limestone, cycle ' $a$ ', Shoal Fringe cycle type. Arrow points to direction of top. Section Portilla de Luna (P). G) Very coarse-grained bioclastic crinoidal grainstone (CR1) Crémenes Limestone. Section Aguasalio (AG). H) Base of the Crémenes Limestone showing the crinoidal grainstone facies (CR1) followed by the boundstone facies (CR2) with stromatoporoids and branching Disphyllum coral, and an upward decrease of shale matrix grading to massive boundstone. Arrow points to direction of top. Section Aguasalio (AG).

Figura 3. A) Sección de Llombera (LL) que muestra la Formación de Portilla (P), el miembro Gordón (G) con las Calizas del Molino, las sucesiones granocrecientes en el Miembro Millar (M) y las Formaciones Fueyo a Ermita, y las discordancias devónicas superiores (UDU). B) Icnofauna de la facies Skolithes en grainstones arenosos (FT2b) de las Calizas del Molino, ciclo tipo 'a', sección de Huergas (H). C) Grainstones arenosos y ferruginos con estratificación cruzada (FT2b) de las Calizas del Molino, ciclo 'a'. La flecha apunta hacia la dirección de la parte superior. Sección Saguera (S). D) Sección de Beberino que muestra la superficie erosiva entre la Formación de Portilla (P) y el Miembro Gordón de la Formación de Nocedo (G). E) Limos y lutitas laminadas y capas delgadas de areniscas. La flecha apunta hacia la dirección de la parte superior. Miembro de Millar. Sección Llombera (LL). F) Calizas arenosas y areniscas calcáreas (FT2b) de las Calizas del Molino, ciclo 'a', ciclo del tipo franja de bancos. La flecha apunta hacia la parte superior. Sección Portilla de Luna (P). G) Grainstone bioclástico muy grueso (CR1) Caliza de Crémenes. Sección Aguasalio (AG). H) Base de la Caliza de Crémenes que muestra grainstones de crinoides (CR1) seguida por la facies de tipo boundstone (CR2) con estromatoporidos y corales Disphyllum, que gradan a boundstone masivos. La flecha apunta hacia la parte superior. Sección Aguasalio (AG). 

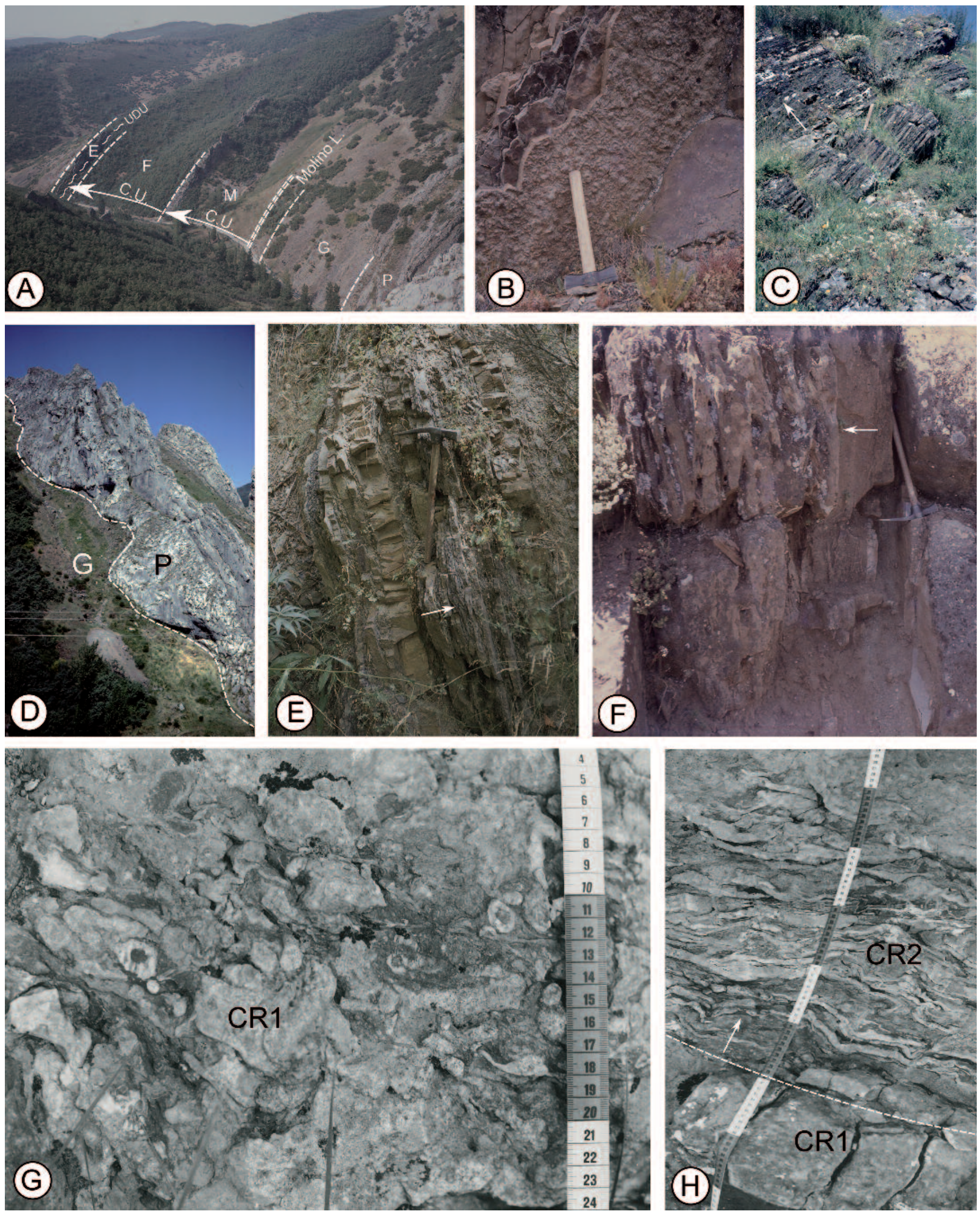
cession of the Gordón Member with the lithological interpretations and the Molino Limestone shaded grey (interpretations modified after Loevezijn, 1986).

Varga Limestone: In the Aguasalio syncline a $9 \mathrm{~m}$ to $11 \mathrm{~m}$ thick carbonate-mudstone succession occurs at the base of the Millar Member. Locally in the eastern part of the Peña Corada Unit, an up to $1 \mathrm{~m}$ thick carbonate-mudstone intercalation occurs at the same stratigraphical level. The succession consists of a lower shaly carbonate and an upper pure carbonate unit. It rests with a sharp contact on the coarse grainstones of the Molino Limestone and has a gradational contact with the overlying grey calcareous shales (Fig. 5). The lower unit of $2.8 \mathrm{~m}$ thick includes purple calcareous shales with mudstone lenses containing large amounts of bryozoans and brachiopods and is only exposed in the Aguasalio section. It passes upward into a $9.2-10.8 \mathrm{~m}$ thick, massive, $30-200 \mathrm{~cm}$ bedded, barren, grey carbonate mudstone unit, with a thin bedded mudstone succession on the top. Locally the mudstones are dark grey and bituminous. Benthic fossils are rare in the massive mudstones, although a few brachiopods (Atrypa spec.) are present. In order to differentiate this limestone more clearly from the underlying Molino Limestone it is herein named the Varga Limestone - after the nearby village Santa Olaja de la Varga with the Santa Olaja section (Fig. 5) as type section. It can be lithologically distinguished from the underlying Molino Limestone and from the overlying siliciclastic Millar deposits and is geographically restricted to the Aguasalio syncline and the Peña Corada Unit. In the lower shale unit no evidence is found of traction currents indicating a low energy environment below wave base, with clay and carbonate mud fallout from suspension. The rich bryozoanbrachiopod assemblage and the large amount of micrite indicate an open marine environment just below thewave base (Machel and Hunter, 1994). The

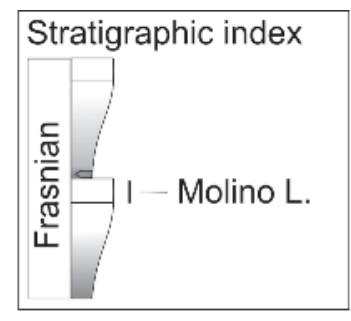

\section{Lithology}

Interpretation

Basin stage

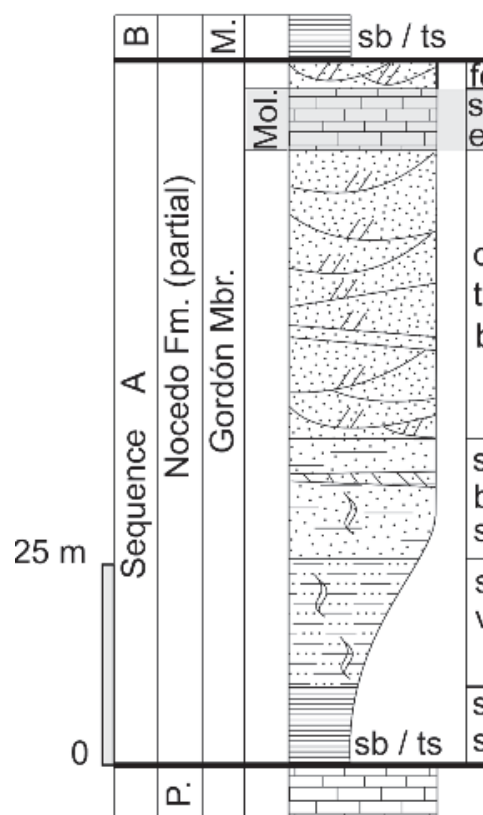

\begin{tabular}{|c|c|c|c|}
\hline $\begin{array}{l}\text { ferruginous quartz aren. } \\
\text { sandy, biocl. limestones } \\
\text { erosion surfaces }\end{array}$ & $\begin{array}{l}\text { upper shoreface } \\
\text { bioclastic shoal }\end{array}$ & condensed & 4 \\
\hline $\begin{array}{l}\text { quartz arenites } \\
\text { trough and tabular cross- } \\
\text { bedding }\end{array}$ & upper shoreface & \multirow{3}{*}{ progradational fill } & 3rd order cycle \\
\hline $\begin{array}{l}\text { silty quartz arenites } \\
\text { bioturbated } \\
\text { some lam., ripple cross-b. }\end{array}$ & lower shoreface & & \\
\hline $\begin{array}{l}\text { sandy siltstones } \\
\text { very bioturbated }\end{array}$ & transition & & \\
\hline $\begin{array}{l}\text { shale and laminated siltst. } \\
\text { slightly bioturbated }\end{array}$ & offshore & deepening & \\
\hline
\end{tabular}

Figure 4. Schematic representation of the Gordón Member with the Molino Limestone shaded grey, based on the measured sections; after Loevezijn (1986). P = Portilla Limestone; Mol. = Molino Limestone; M. = Millar Member.

Figura 4. Representación esquemática del miembro Gordón con las Calizas del Molino sombreada en gris. Tomado de Loevezijn (1986). P = Caliza de Portilla; Mol. = Calizas del Molino; M. = Miembro Millar. 
van Loevezijn, G.B.S. and Raven, J.G.M., 2017. Frasnian carbonate shoals and sequence... Boletín Geológico y Minero, 128 (4): $931-961$

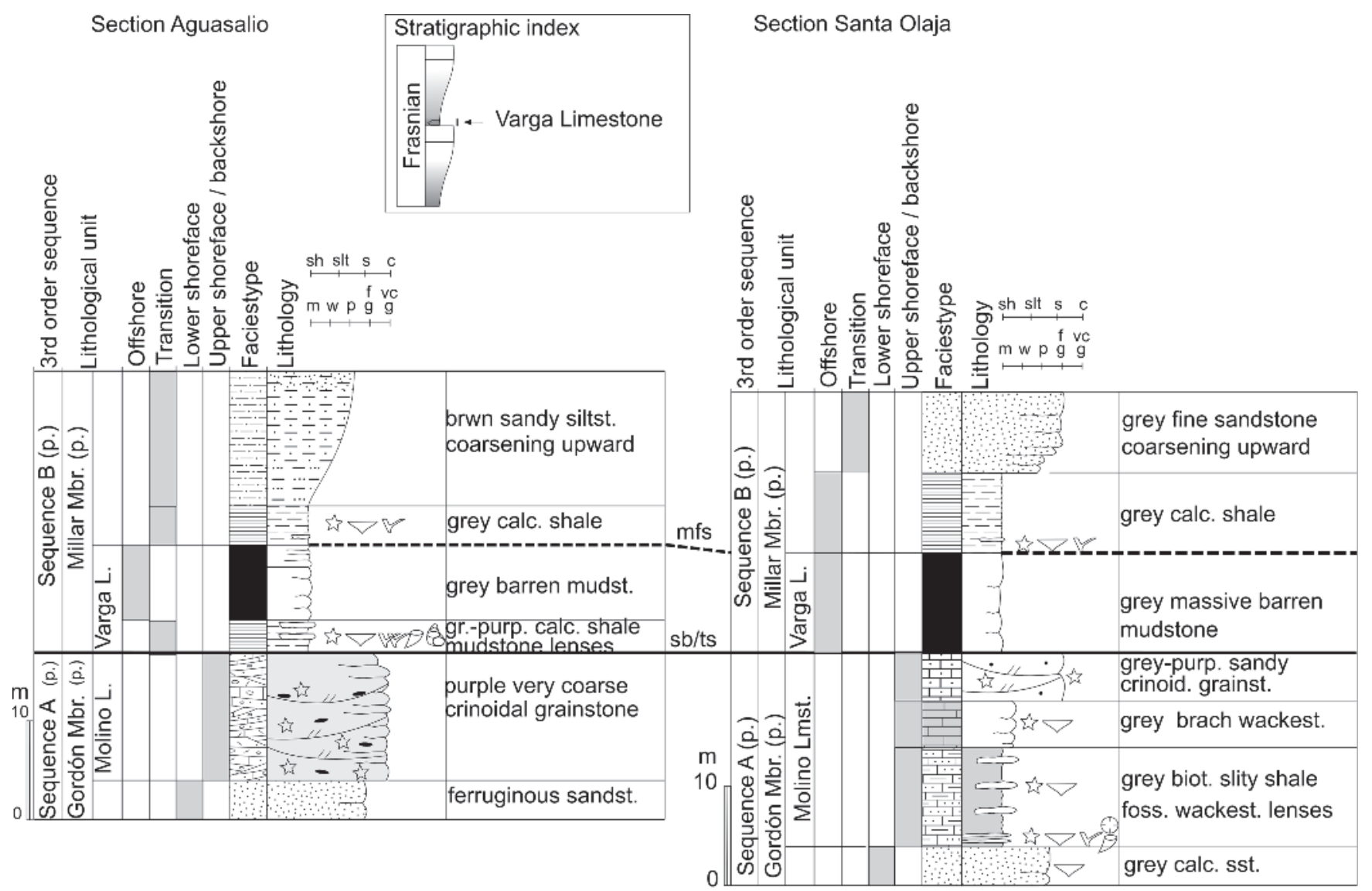

\begin{tabular}{|c|c|c|c|}
\hline 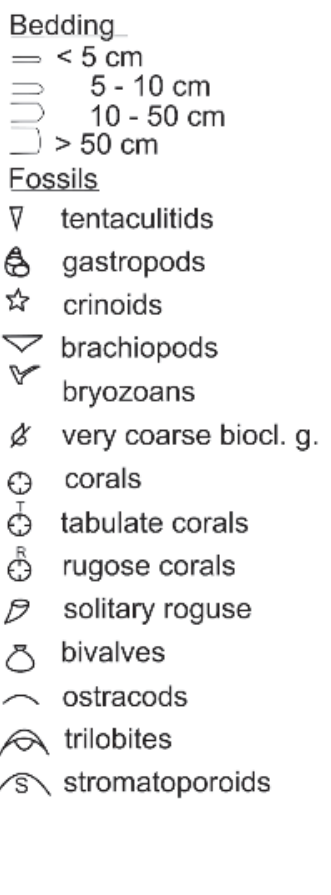 & $\begin{array}{l}\text { Lithology } \\
\square \text { purple limestone } \\
\square \text { light grey limestone } \\
\text { sandy limestone } \\
\text { dolomitic limestone } \\
\text { c.g condstone } \\
\text { f.g fine grainstone } \\
\mathrm{P} \text { packstone } \\
\text { w wackestone } \\
\mathrm{m} \text { mudstone } \\
\text { sh shale } \\
\text { slt silt } \\
\text { s sandstone } \\
\text { cgl conglomerate } \\
\text { Cycle patterns } \\
1 \text { backshoal } \\
2 \text { core } \\
3 \text { core - fringe } \\
4 \text { fringe }\end{array}$ & $\begin{array}{l}\text { Molino Lmst. facies types } \\
\text { FT1a } \\
\text { FT1b } \\
\text { FT2a } \\
\text { FT2b } \\
\text { Overlying - underlying facies types } \\
\text { limestone } \\
\text { seefal limestone } \\
\text { siltstone - very fine grained sst. } \\
\text { laminated shale } \\
\text { micritic limestone } \\
\text { Deposit. energy, Facies } \\
\square \text { migh, shoal core } \\
\text { low, backshoal } \\
\text { Cycles }\end{array}$ & 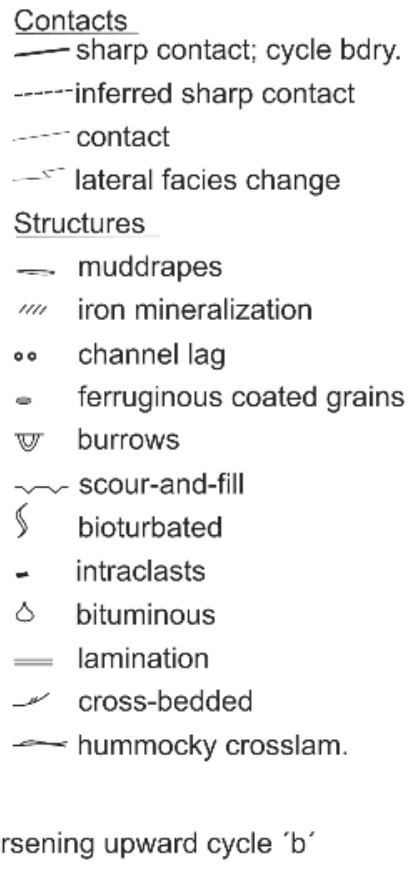 \\
\hline
\end{tabular}

Figure 5. The measured sections in the Aguasalio syncline with the Molino Limestone and the Varga Limestone and the main sequence stratigraphical boundaries. $\mathrm{sb}=$ sequence boundary, $\mathrm{ts}=$ transgressive surface, $\mathrm{mfs}=$ maximum flooding surface.

Figura 5. Las secciones medidas en el sinclinal de Aguasalio con las Calizas del Molino y la Caliza de Varga y los límites estratigráficos de la secuencia principal. $\mathrm{Sb}=$ límite de secuencia, ts = superficie transgresión, mfs = superficie de máxima inundación. 
suspended sediment may have reduced the photic zone, however, the in situ occurrence of bryozoans and brachiopods indicates a benthic fauna could still have thrived. The overlying carbonate mudstones appear to have been formed by fallout from suspension in a low-energy environment. The lack of interwoven coarser-grained deposits indicates deposition away from any currents. Since the mud-rich lower unit contains abundant benthos, in the upper unit the almost complete absence of macrobenthos may be due to the combination of several factors: the lack of a stable substrate to attach to, unfavourable water bottom conditions caused by oxygen depletion and/or a high concentration of suspended mud which made the photic zone shallower. The vertical and lateral relationships with the outer-shelf shales and the absence of benthos and coarse-grained sediment suggest deposition away from the coast below wave base, in the deepest and most distal setting of the ramp. In vertical successions an abrupt facies shift occurs between relatively deeper-water mudstone facies of the distal ramp lying directly on top of the shallow marine shoal deposits of the inner ramp. The shale and mudstone deposits represent the deepening stage of third- order sequence $B$ of the overlying Millar Member. These sediments were deposited in lateral continuity to the overlying shale deposits of sequence $B$, and are not genetically related to the underlying shoal deposits of the Molino Limestone of sequence $A$.

Crémenes Limestone: The Crémenes Limestone of Westbroek (1964) is a $15-20$ m thick carbonate succession in the Aguasalio syncline and the eastern part of the Peña Corada Unit, with a coral - stromatoporoid reef succession, and represents the last Devonian reef development in the Cantabrian Mountains (Loevezijn et al., 1986; García Alcalde, 2012). It consists of a shoal facies with cross-bedded sandy grainstones, ferruginous coated grains and coarse bioclastic debris (CR1), a reef facies with massive light grey boundstones (CR2) and argillaceous bindstones and bafflestones (CR3), and a fore reef facies consisting of thin-bedded mudstones, wackestones and packstones (CR4) and medium-bedded fine-grained grainstones (CR5) (Fig. 6). The bioclastic debris of facies CR1 is interpreted as the stabilisation stage on which the coral-stromatoporoid reefs developed (Loevezijn, 1987) (Figs. 3G, $3 \mathrm{H})$.

\section{Sequence stratigraphy}

The cycles and sequence boundaries that form the basis for the sequence stratigraphic interpretation in this paper are established in individual sections, determined by the location of the erosional boundary surfaces within the sections, and the vertical stacking of facies types in between these boundaries. First the Frasnian deposits will be organised into a sequence stratigraphical model and the position of the Molino Limestone in that model will be established. Subsequently the lower order cyclicity of the Molino Limestone will be unravelled, by organising the Molino facies stacking patterns.

\section{Large-scale cycles}

The key to sequence stratigraphy is the identification of the major bounding surfaces, generated due to changes in relative sea-level resulting from global/regional eustatic sea-level changes, regional/local structural movements or a combination. For boundary surfaces to be considered sequence boundaries the surfaces should be sharp (often erosional), regionally extensive and accompanied by abrupt facies shifts.

Three Frasnian sequence boundaries have been identified (Fig. 7). The first one is located at the base of the Frasnian Nocedo Formation, a sharp surface characterised by hardgrounds and dolomitisation (Loevezijn, 1987). At Beberino (section B) the bounding surface displays several meters of relief (Herbig and Buggish, 1984; Loevezijn, 1986) (Fig. 3D). The second one is a sharp surface at the base of the Millar Member (Fig. 8), indicating a facies jump from upper shoreface sandstones (FT3) or crinoidal shoals (FT2) to offshore shales or mudstones. In the Aguasalio syncline the second sequence boundary is a sharp contact between the shoal deposits of the Molino Limestone and the overlying mudstones of the Varga Limestone. Elsewhere the second sequence boundary is located between the ferruginous shoreface sandstones overlying the Molino Limestone (Gordón Member) and the shales at the base of the Millar Member. The contact is well exposed in the outcrops of the river Torío near the old water mill (section Matallana; Fig. 8), where shales of the Millar Member mantle the ferruginous calcareous cross-laminated sandstones of the underlying Gordón Member. The boundary bed below the contact contains debris of large gastropods, brachiopods and crinoid stems up to $8 \mathrm{~cm}$ long.

The third boundary is a sharp erosive contact with a shift in facies from cross-laminated upper shoreface sandstones (Frasnian Millar Member) to offshore shales (Famennian Fueyo Formation; Loevezijn 1986). In the Matallana section the upper portion of the 


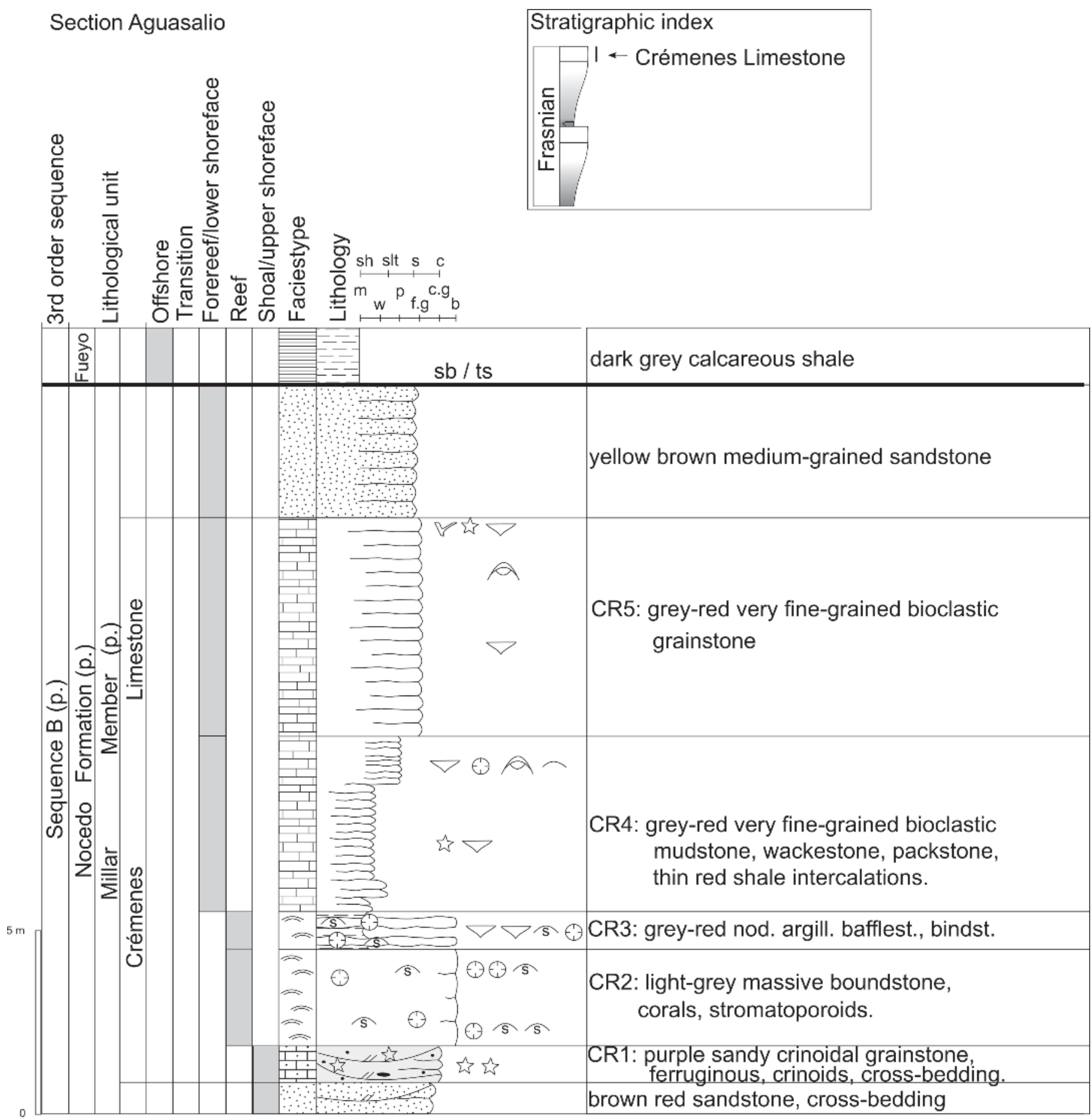

Figure 6. Type section of the Crémenes Limestone in the Aguasalio syncline. Lithological subdivision CR1 to CR5 after Loevezijn et al., 1986. For legend see Figure 5.

Figura 6. Subdivisión litológica CR1 a CR5 en la sección tipo de los la Caliza de Crémenes en el sinclinal de Aguasalio. Tomado de Loevezijn et al., 1986. Para leyenda vea la Figura 5.

Frasnian succession is well exposed and the contact between the Frasnian and Famennian deposits displays several meters of relief (Fig. 8). In most sections however, the bounding surfaces are para-conformable with no apparent erosional relief and the surface resembles a simple sharp bedding plane. 
Figure 7 summarises the Frasnian sequence stratigraphic model. Two cycles are recognised, herein called A and B, each containing a Transgressive Systems Tract (TST) and a Highstand Systems Tract (HST) of Van Wagoner et al. (1988) and Catuneanu et al. (2011), with the Molino Limestone positioned at the top of cycle $A$ and the Crémenes Limestone at the top of cycle B. In the standard hierarchy of stratigraphic cycle order of Vail et al. (1977) third- order cycles have a duration in the range of 1-10 MY. The two Frasnian large-scale cycles fall approximately within this range.

\section{Basin stages and small-scale cycles}

Within each of the third- order cycles three stages can be recognised: deepening, progradational fill and condensed.

The deepening stage correlates with the TST. The lower boundary is represented by a stark erosional surface and an abrupt shift towards a deeper and more distal depositional environment indicating a pronounced deepening of the basin. The overlying laminated shales and siltstones contain a fining upward package indicating a decrease of energy caused by the relative sea-level rise (transgressive interval). The boundary between this fining upward package and the overlying coarsening upward package is interpreted as maximum flooding surface (mfs; see Matallana section: Fig. 8). In sequence ' $B$ ' of the Aguasalio unit the $\mathrm{mfs}$ is positioned at the boundary between the mudstones of the Varga Limestone, representing the deepest ramp setting, and the overlying calcareous shales (Fig. 5).

The progradational fill stage correlates with the HST. Within the HST a stack of small-scale cycles or parasequences (Vail, 1977; Catuneanu et al., 2011) was recognised. Each siliciclastic small-scale cycle contains a somewhat shallower facies than the small-scale cycle before, producing an overall shallowing and coarsening upward trend within the entire stacking (Matallana section: Fig. 8). The facies stacks display a particular suite of genetically related facies types in a shallowing

\section{Systems tracts}

Frasnian 3rd order sequences

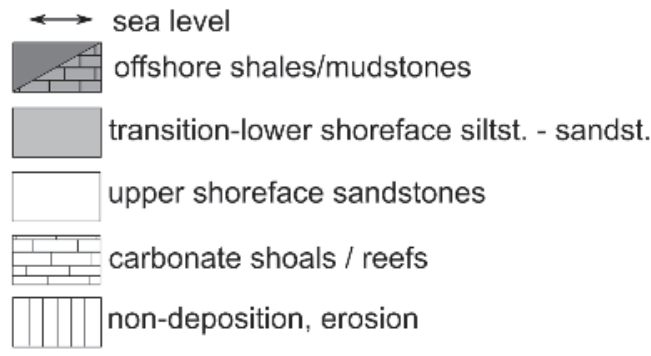

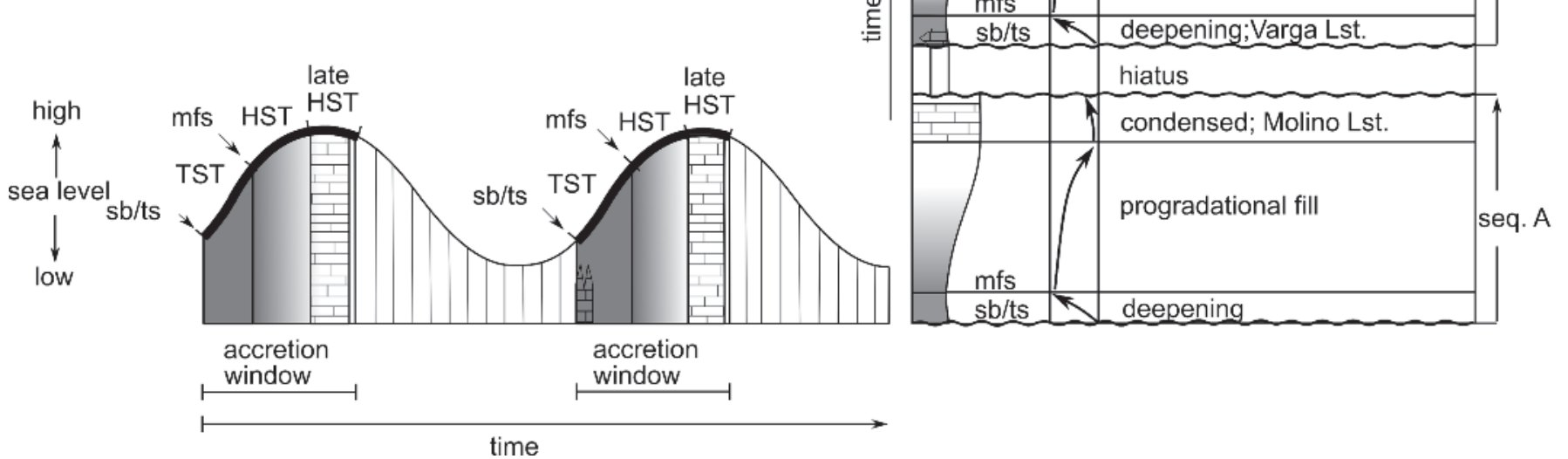

Figure 7. Frasnian sequence stratigraphic model with the position of the carbonate shoals. sb $=$ sequence boundary, ts $=$ transgressive surface, $\mathrm{mfs}=$ maximum flooding surface, TST = transgressive systems tract, $\mathrm{HST}=$ highstand systems tract.

Figura 7. Modelo estratigráfico de la secuencia del Frasniense con la posición de los bancos de carbonato. Sb = límite de secuencia, ts = superficie transgresión, $\mathrm{mfs}=$ superficie de inundación máxima. 
upward order from silty shales at the base, via hummocky cross laminated and bioturbated sandstones, towards trough cross-bedded sandstones in the uppermost part (regressive interval).
The overlying condensed stage represents a time of carbonate dominance when the relative sea- level rose at ever lower rates. When the accommodation space was almost filled and the topography low, siliciclastic

Santa Olaja

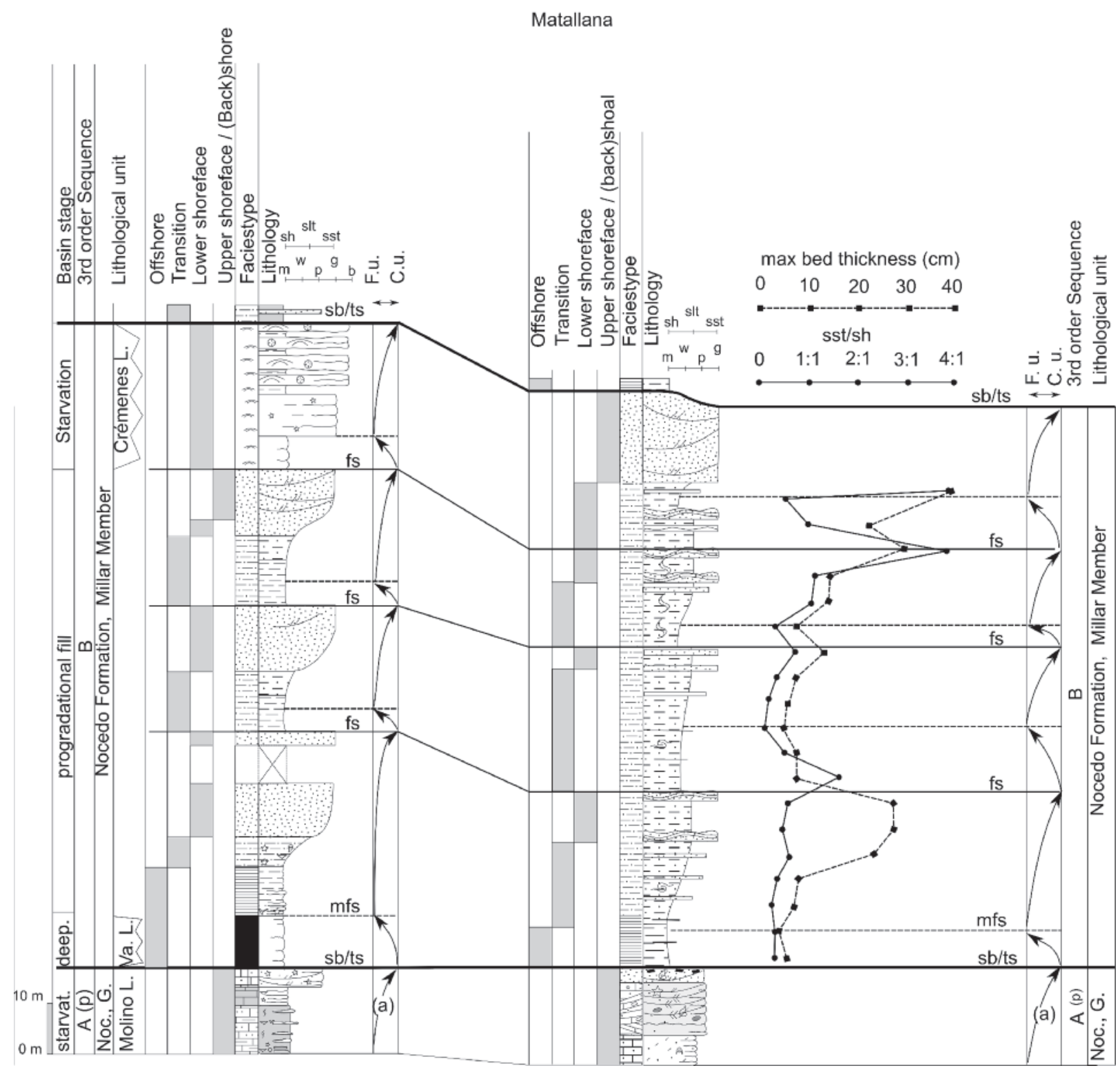

Figure 8. Overview of the Molino Limestone and overlying deposits in the Santa Olaja de la Varga and Matallana sections. The carbonate mudstone unit of the Varga Limestone is genetically related to the deepening stage of the third- order sequence of the overlying Millar Member. As a consequence the sequence boundary is located at the base of the mudstone interval. Note the gradual upward transition from the carbonate mudstone into the shale. Noc. G. $(p)=$ Nocedo Formation, Gordón Member (partial); Va = Varga Limestone. For legend see Figure 5.

Figura 8. Caliza del Molino y los depósitos suprayacentes en las secciones de Santa Olaja de la Varga y Matallana. La unidad de Caliza de Varga es de tipo mudstone y está genéticamente relacionada con la etapa de profundización de la secuencia de tercer orden del miembro de Millar que lo cubre. Como consecuencia, el límite de secuencia se localiza en la base del intervalo de mudstone. Obsérvese la transición gradual hacia arriba de mudstone a lutitas. Noc. G. $(p)$ = Formación de Nocedo, Gordón Miembro (parcial); Va = Caliza de Varga. Para la leyenda vea la Figura 5. 
van Loevezijn, G.B.S. and Raven, J.G.M., 2017. Frasnian carbonate shoals and sequence... Boletín Geológico y Minero, 128 (4): $931-961$

input ceased: the basin became sediment starved and a condensed carbonate succession (the Molino Limestone) developed, representing the late HST.

No Lowstand Systems Tract (LST) sediments of the three-systems-tract model were recognised in the Upper Devonian deposits. Therefore the boundaries between the sequences are defined by discontinuity surfaces between HST andTST that can often be interpreted as combined sequence boundaries/transgressive surfaces (sb/ts; van Wagoner et al., 1988; Catuneanu et al., 2011). The absence of a LST succession in the Cantabrian Upper Devonian may indicate the relative landward position of the measured sections on the shelf. Sediments may have bypassed this area and been deposited further to the $S$ and $W$, in more distal and deeper depositional areas which are more favourable for the deposition and preservation of LST sediments. These areas are not exposed in the south-western Cantabrian Mountains.

\section{The Molino Shoal complex}

\section{Biostratigraphy}

The Molino Limestone contains rich conodont faunas, which have been studied by many authors (Raven, 1983; García-López, 1987; García-López and Sanz López, 2002 amongst others). The following conodont zones were recognised (García-López and SanzLópez, 2002): Upper Mesotaxis falsiovalis Zone, Palmatolepis transitans Zone, Palmatolepis punctata Zone and Lower Palmatolepis hassi Zone. In addition to the conodont faunas the limestone is also rich in other microscopic and macroscopic fauna elements. Raven $(1980,1983)$ recorded the following fossils:

- Sponges: spicules, stromatoporoid clasts and coralline demosponge: Chaetetes spec.

- Corals: solitary rugose corals: Alveolites

- Bryozoans: fenestrate bryozoans

- Echinoderms: columnalia of crinoids

- Brachiopods: Apousiella bouchardi (Murchison, 1840); Athyris spec.; Atrypa spec.; Cariniferella dumontiana (de Verneuil, 1850); Cyrtina spec.; Cyrtospirifer spec.; Gypidula spec.; Chonetes spec.; Productella subaculeata Murchison, 1840; "Productus" spec.; "Rhynchonella"spec.; "Spirifer" s.I.

- Molluscs: pelecypods and gastropods: Platyceras spec.

- Tentaculites: Tentaculites spec.; Homoctenus ultimus Zagora, 1964

\section{Facies types}

Based on their lithological features and faunal content the carbonates of the studied interval can be grouped into a number of facies types (FT). The facies types are units which, based on the description given here, should be recognisable in the field. Sometimes arbitrary boundaries were inevitable, especially where contacts between the facies types are gradational. The lithofacies types are compared with the facies zones and Ramp MicroFacies types (RMF) of Flügel (2004), the facies zone subdivision of the homoclinal carbonate ramp of Burchette and Wright (1992), and the facies belts of Schlager (2005), a modified subdivision of the standard facies belts of Wilson (1975). Carbonates are classified according the system of Dunham (1962) and Embry and Klovan (1971).

Facies type 1: mudstones, wackestones and packstones

This facies type consists of mud-supported limestones and packstones with silty intercalations. It is split into a wackestone-packstone subtype of silty carbonates, and a mudstone-wackestone subtype of pure carbonates.

Facies subtype 1a: calcareous siltstones and silty wackestones and packstones

Description: Facies subtype 1a (FT1a) consists of thin irregularly bedded, nodular bioclastic silty wackestones and packstones. Homogeneously admixed as well as alternating limestone and shaly siltstone successions occur. The sediments are locally admixed with a variable amount of very fine sand and are significantly burrowed and bioturbated. In the Alba syncline the silt content varies from 10 to $20 \%$, with some parts up to $50 \%$. In the eastern part of the Peña Corada unit and in the Aguasalio syncline this facies type locally passes into calcareous nodular shale with limestone lenticles. Generally the rocks have a grey colour, but mottled red coloured beds also occur. The ferric oxides responsible for the red colour occur as finely dispersed material within micritic beds. FT1a occurs in the basal part of the Molino Limestone. The boundary with the overlying cross-bedded sandy limestones of FT2b is gradual. In the Esla area a succession of grey bioclastic wackestones and mudstones of FT1 $\mathrm{b}$ is intercalated between the silty limestones of FT1a and the overlying cross-bedded sandy carbonates. 
van Loevezijn, G.B.S. and Raven, J.G.M., 2017. Frasnian carbonate shoals and sequence... Boletín Geológico y Minero, 128 (4): $931-961$

Sediments of FT1a are generally poorly sorted (Fig. 9A). The silt sized quartz grains are angular. The very fine quartz grains are subangular to poorly rounded. In the Huergas section large amounts of small, thin shelled brachiopods and small crinoids occur. In the La Ercina section the brachiopods Productus spec, "Rhynchonella"spec., Chonetes spec., Cyrtospirifer spec., Apousiella bouchardi (Murchison, 1840), abundant Cariniferella dumontiana (de Verneuil, 1850), Cyrtina spec., and abundant Atrypa spec. can be observed. Solitary rugose coral Alveolites, the coralline demosponge Chaetetes spec., gastropods Platyceras spec. and crinoid ossicles occur. In the Santa Olaja section the brachiopods Atrypa spec. and Apousiella bouchardi (Murchison, 1840) were found.

Interpretation: The completely bioturbated nodular sediment and the absence of cross-bedded lamination suggest quiet water conditions. The undisturbed disarticulated crinoid ossicles suggest a low rate of sedimentation, allowing time for organic matter binding the ossicles together to decay (Lane, 1971). The lower contact of FT1a is not exposed anywhere in the Bernesga area. Towards the top of FT1a the silty deposits grade upward into sandy sediments. The gradual boundary with the overlying cross-bedded sandy limestone of FT2b suggest a close relationship between the quiet water environment of FT1a and the turbulent environment of the overlying sandy limestones of FT2b. The poorly rounded, poorly sorted, moderately fossiliferous, mud supported limestones were described as bioturbated variably bedded lagoonal lime mudstones, packstones and wackestones of the lagoonal inner ramp facies belt B of Bruchette and Wright (1992) and resemble the echinodermal bioclastic packstone deposits of the protected low-energy environment RMF7 of Flügel (2004). In the classification of Schlager (2005) the deposits belong to open lagoonal facies belt 7. The lagoonal carbonate facies types can be very sandy (e.g. de Coo, 1974; Hofmann and Keller, 2005). It is concluded that the sediments of FT1a were deposited in a protected platform with a limited sediment supply sheltered from the open sea by a bar or barrier, with terrigenous siliciclastic input. However the development of fully lagoonal conditions is unlikely because of the diverse brachiopod fauna and the abundance of crinoids, which requires the persistence of frequent water exchange of an open lagoonal environment (Remane and Schlieger, 1971; Machel and Hunter, 1994; Schlager, 2005).
Facies subtype 1b: fossiliferous wackestones and mudstones

Description: Facies subtype 1b (FT1b) occurs in the Esla area in the lower part of the Molino Limestone. It consists of light grey and dark grey mudstones with fossiliferous wackestone intercalations. It is a relatively pure carbonate facies with less than $10 \%$ siliciclastic admixture. Bedding ranges from nodular thin bedding $(1-10 \mathrm{~cm})$ to medium bedding $(5-20 \mathrm{~cm})$. Locally the mudstones are bituminous with a dark grey to black colour. Fossils are restricted to the wackestone intercalations and consist of crinoids, brachiopods (including Atrypa spec. and "Spirifer"s.I.), oysters, gastropods, and branching and solitary corals. FT1b is often sandwiched between the underlying silty limestones of FT1a and the overlying grainstones of FT2b or FT2c.

Interpretation: The mudstones are poor in benthic fossils. This could be due to the lack of a stable substrate to attach to and/or unfavourable, stressed bottom conditions. The dark bituminous nature of the sediment could be an indication of oxygen depleted conditions (Arthur and Sageman, 2004). The fossiliferous concentrations were formed when the environmental conditions temporarily improved. They could have been transported in by waves or slow currents (although the deposits lack recognisable structures indicating current or wave action). Hofmann and Keller (2005) grouped similar Middle Devonian carbonates into a sheltered intertidal to supratidal facies association. Based on our data and observations we assume a semirestricted open lagoonal depositional environment where generally dark micritic sediments (mudstones) were deposited; periodical water exchange with the open sea (Schlager, 2005), resulted in rich fossiliferous wackestone intercalations. A good example for this palaeo-environment was described for the shallow-water limestones in the Givetian to Frasnian Cima Ombladet succession, Carnic Alps, Italy (Galli, 1985). The deposits fall into inner ramp type $B$ of the homoclinal carbonate ramp subdivision of Burchette and Wright (1992): the lagoonal mudwackestone and packstone facies. According to the microfacies types of Mesozoic and Palaeozoic ramp carbonates of Flügel (2004) the deposits fall into the protected-lagoonal low-energy ramp setting, with the RMF7 and RMF19 types: mudstones and packstones characterised by skeletal grains in different quantities. In the classification of Schlager (2005) the deposits belong to open lagoonal facies belt 7. The bituminous dark mudstones represent times of stagnated nonturbid quiet water, whereas the fossiliferous wackestone intercalations suggest a temporal change in 

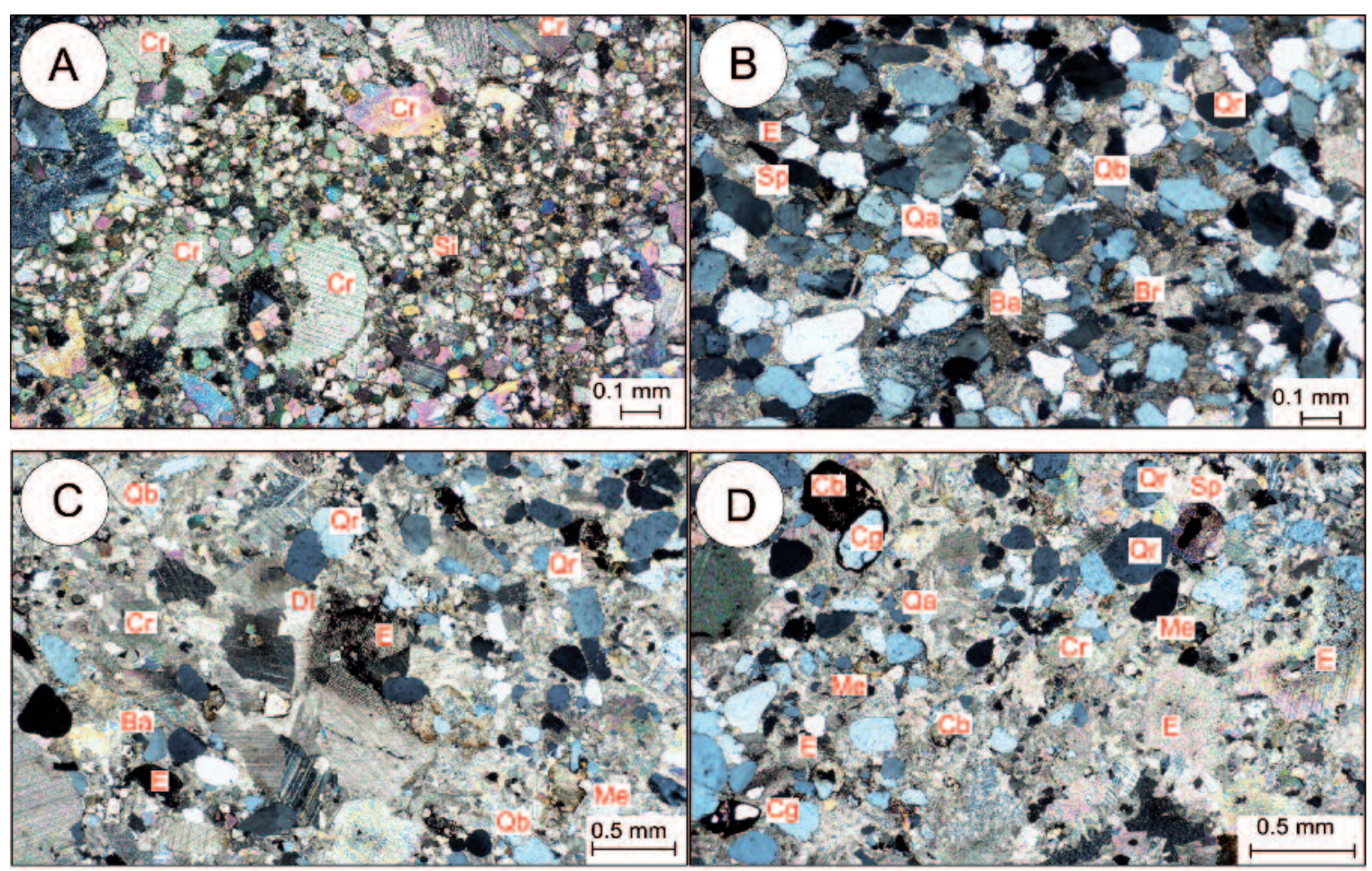

E)

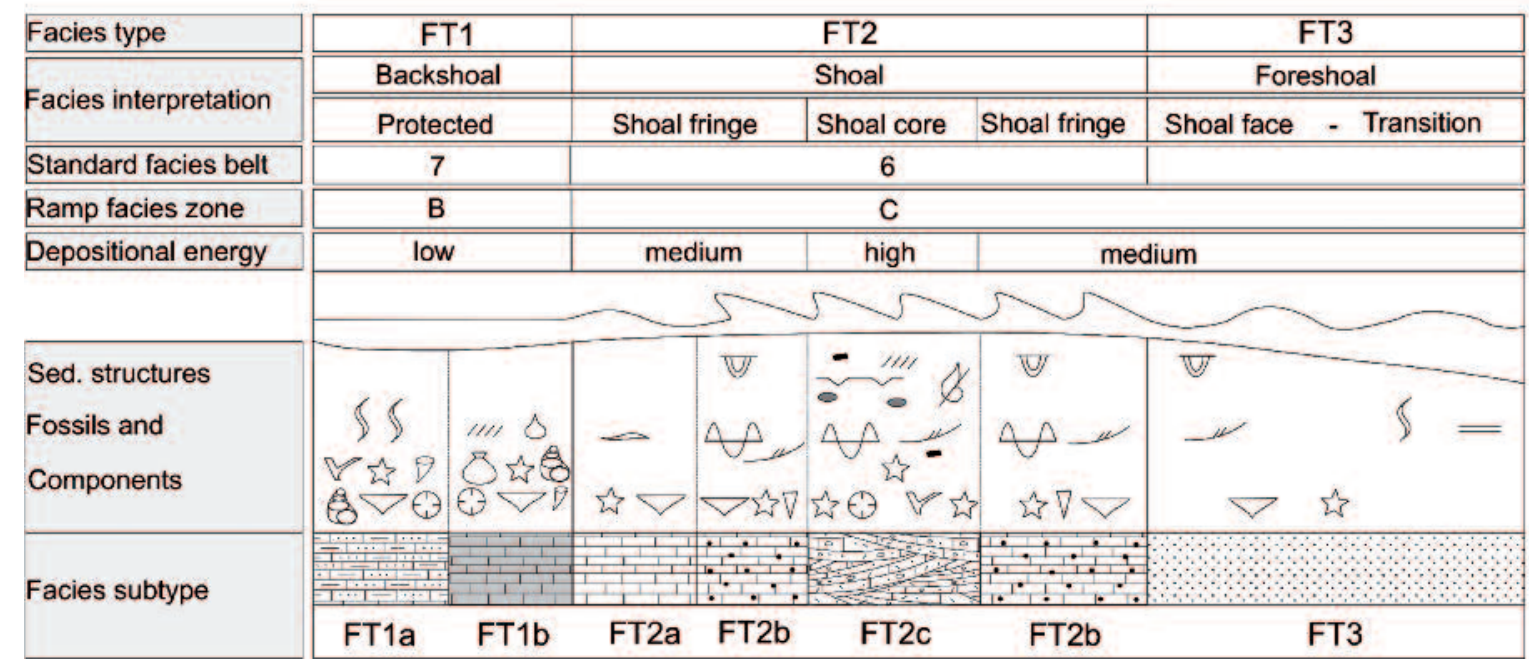

Figure 9. A) FT1a, Crossed nicols photomicrograph of sample H32_03, calcareous siltstone. B) FT2b, Crossed nicols photomicrograph of sample H35_04, calcareous quartz sandstone. C) FT2c, Crossed nicols photomicrograph of sample H48_02, bioclastic grainstone. D) FT2c, Crossed nicols photomicrograph of sample H48_01, bioclastic grainstone. Cr=crinoid ossicle; $\mathrm{Si}=$ angular silt grain; $\mathrm{Br}=\mathrm{bry}$ ozoan; $\mathrm{Ba}=\mathrm{bra}-$

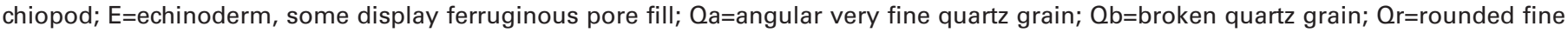
quartz grain; $\mathrm{Cg}$ =ferruginous coated quartz grain; $\mathrm{Cb}=$ ferruginous coated bioclast; $\mathrm{Sp}=\mathrm{sparitic}$ overgrowth; $\mathrm{Dt=dog}$ tooth cement; $\mathrm{Me}=$ micrite envelope. E) Cross-section across the shallow mixed siliciclastic-carbonate ramp of the Molino Limestone, illustrating the lithofacies types, depositional energy, ramp facies classification (according to Burchette and Wright, 1992) and standard facies belt classification (according to Schlager, 2005).

Figura 9. A) FT1a, fotomicrografía de nicoles cruzados de la muestra H32_03, limolita calcárea. B) FT2b, fotomicrografía de nicoles cruzados de la muestra H35_04, cuarzoareinta calcárea. C) FT2c, fotomicrografía de nicoles cruzados de la muestra H48_02, grainstone bioclástico. D) FT2c, fotomicrografía de nicoles cruzados de la muestra H48_01, grainstone bioclástico. Cr = osículo de crinoide; Si = grano anguloso; $\mathrm{Br}=$ briozoo; $\mathrm{Ba}=$ braquiópodo; $E$ = equinodermo, algunos feruginizados; $Q \mathrm{a}=$ grano anguloso de cuarzo; $\mathrm{Qb}=$ grano de cuarzo roto; $\mathrm{Qr}$ = grano de cuarzo fino redondeado; $\mathrm{Cg}$ = grano de cuarzo con envuelta ferruginosa; $\mathrm{Cb}=$ bioclasto con envuelta ferruginosa; $S p=$ recrecimiento esparítico; $D t=$ cemento en diente de perro; Me = envuelta micrítica. E) Corte transversal a través de la rampa carbonática con sedimentación mixta (Calizas de Molino), ilustrando los tipos de litofacies, la energía de sedimentación, la clasificación de los cinturones de facies (según Burchette y Wright, 1992) y la clasificación estándar de cinturón de facies (según Schlager, 2005). 
water conditions creating a more favourable environment for the benthic communities.

\section{Facies type 2: grainstones}

This facies type consists of bioclastic and sandy grainstones, with a fine-grained bioclastic subtype, a sandy subtype, and a coarse-grained bioclastic subtype.

\section{Facies subtype 2a: fine-grained bioclastic grainstones}

Description: Facies subtype 2a (FT2a) is well developed in section $H$, where it is sandwiched between coarse bioclastic cross-laminated grainstones of FT2c. The sediments consist of grey to light brown coloured, fine bioclastic grainstones. The bedding is well developed with $10 \mathrm{~cm}$, locally up to $20 \mathrm{~cm}$ thick beds. The bedding surfaces are wavy and slightly erosive. Locally thin (cm thick) silt drapes occur as grey, green and red lenses between the limestone beds. Bioturbation can be observed in some of the silt drapes. Crinoids and brachiopods form the majority of the bioclasts.

Interpretation: The sediments were formed just outside the zone of highest energy, probably as a transitional facies between the high-energy coarse bioclastic carbonate deposits of FT2b and FT2c, and the low-energy back shoal deposits of FT1. The sharp, slightly erosive bedding surfaces indicate deposition in slightly disturbed water eroding the underlying fine-grained fossil debris. In this facies no coarse bioclastic particles occur and the admixed quartz grains do not surpass the very fine to fine grain size. Due to abrasion the quartz grains were smoothed into subrounded to rounded clasts. Locally fines could settle down, indicating quiet conditions within the generally agitated environment. The deposits belong to facies belt C; the shoal facies with bioclastic grainstones and packstones of the homoclinal carbonate ramp subdivision of Burchette and Wright (1992). In the classification of Schlager (2005) the deposits belong to grainstone facies belt 6 with calcarenites and lime sand. Flügel (2004) classified similar deposits as RMF27 with bioclastic grainstones and packstones.

\section{Facies subtype $2 b$ : sandy grainstones}

Description: Facies subtype $2 \mathrm{~b}$ (FT2b) sediments occur in most of the investigated Molino sections. This facies type consists of grey brown to red fine- grained sandy grainstones with a variable bioclastic content and with a gradational transition to calcareous quartz sandstones with sandy lenses, resulting in a mixed carbonate-siliciclastic sediment (Fig. 9B illustrates a calcareous sandstone from such a sandy lens). Locally a sandy dolomite is intercalated. Bed thickness varies from $10-50 \mathrm{~cm}$. The bed surfaces are sharp, locally wavy and often clearly erosive. Trough cross-lamination occurs frequently (Figs. 3C, 3F), and also sharp massive beds without internal structures occur. Erosive channel incisions with a coarse bioclastic channel lag of mainly crinoid ossicles admixed with a debris of brachiopods and bryozoans are present. Locally these beds were completely reworked by escape burrows (Fig. 3B). A ferruginous crust occurs in the basal part of the very fine grained sandy grainstone section of La Ercina. Locally thin, $1 \mathrm{~cm}$ thick, beds of very coarse crinoidal debris are intercalated within the facies. The quartz sand consists of angular very fine grains and rounded fine grains, broken quartz grains are frequent. Skeletal clasts of echinoderms (mainly crinoid ossicles), brachiopods (Stopheodonta spec.) and bryozoans occur, locally trilobite fragments were observed.

Interpretation: The sharp erosive bed contacts, the trough cross-lamination, channels and escape burrows indicate a shallow marine agitated water environment with shifting sediment loads of mainly skeletal echinodermal debris and quartz grains, admixed with various types of bioclastic debris. Thin, $\mathrm{cm}$ thick, crinoidal debris intercalations represent bioclastic lag deposits; winnowed surfaces, where bioclastic debris was sorted and concentrated by the currents. The rounded broken quartz grains and the absence of a micritic matrix indicate an agitated water environment (Flügel, 2004). No fines could settle down in the turbulent water environment. The sandy nature of the sediments indicates a complex interplay of tides, waves and currents influencing the sediment transport in the inner ramp environment and mixing carbonate sands with the siliciclastic shore. Similar carbonate siliciclastic mixing was described by Testa and Bosence (1998) for the ocean facing tropical ramp of the coast of Brazil with carbonate sands and siliciclastic belts, where bioclastic deposits became admixed with the sediments of the nearby siliciclastic environment. Ferruginous crusts and iron mineralisation surfaces were observed in this facies type (section LE). Probably the iron derived from the landmass of the Asturian geanticline, the detrital source area north of the Devonian sedimentary basin. Erosion and truncation of ferruginous soil horizons were probably common features in Mid Palaeozoic sediments and, because of the absence, or poor development of root 
van Loevezijn, G.B.S. and Raven, J.G.M., 2017. Frasnian carbonate shoals and sequence... Boletín Geológico y Minero, 128 (4): $931-961$

horizons (Marriott and Wright, 2006), provided the basin with ferruginous detrital sediment. The deposits belong to facies belt $C$, the shoal cross-laminated facies of bioclastic grainstones and packstones of Burchette and Wright (1992) and grainstone facies belt 6 of Schlager (2005). Echinodermal bioclasts make up the major part of the fossil debris and Flügel (2004) classified similar deposits as RMF27: the bioclastic grainstone packstone with a few dominant skeletal grains.

Facies subtype 2c: coarse-grained bioclastic grainstones

Description: Facies subtype 2c (FT2c) is present in the upper part of the Molino Limestone, is composed of intense red to violet-purple coloured, very coarse bioclastic grainstones with locally intercalated sandstone lenses. The well-developed beds are around 20$50 \mathrm{~cm}$ thick. The bedding surfaces are wavy and slightly erosive. Trough cross-lamination occurs frequently, often organised as herringbone structures. The current directions derived from the cross-lamination are strongly bimodal and show a predominant NNE-SSW orientation (rose diagrams; Fig. 14A). Erosion surfaces are present both with a low relief as well as steep channels with a channel lag of lithoclasts, coarse skeletal debris (mainly echinoderms) and ferruginous coated grains (Figs. 9C and 9D). A channel lag in the Peña Corada section comprises large quantities of tentaculites. Micrite envelopes developed around carbonate skeletal fragments, and the carbonates are partly transformed into finegrained calcite. The admixed sandstone consists of very fine-grained poorly rounded to sub-angular quartz grains, and fine-grained rounded to wellrounded quartz grains with a high sphericity. The grains are often broken (Fig. 9C). Ferric oxides are responsible for the red colour and are concentrated on the skeletal grainstones as coatings on various allochems (quartz grains, bioclasts) and as impregnation in bioclast pores (mostly echinoderms). Microborings and micrite envelopes were observed on bioclasts and the sediment is substantially micritised (Fig. 9C) (Sánchez de la Torre, 1977). Bioclasts display iron-stained margins. Peculiar filaments of possible organic nature as described by Ferrety (2005) and Gharaie et al. (2009) were not observed in the coatings. Enormous quantities of large disintegrated echinoderm plates (mainly crinoid and blastoid ossicles) occur, whereas clasts of corals, brachiopods (including Cariniferella dumontiana (de Verneuil, 1850) and Apousiella bouchardi (Murchison, 1840)), bryozoans, gastropods, tentaculites (Tentaculites spec. and Homoctenus ultimus Zagora, 1964) and undeterminable fragments occur in variable quantities.

Interpretation:The erosion surfaces, channel structures, coarse bioclastic lags and reworked fragments of weakly consolidated ferruginous sediment indicate an agitated water environment with a constantly shifting substrate where sediment was reworked by powerful currents. No fines could settle in this turbulent environment. The well-sorted, rounded quartz and the absence of a micritic matrix are further indications of turbulent waters (Flügel, 2004). The palaeo-environment was characterised by a low sedimentation rate as indicated by numerous erosion surfaces, intraclasts, bioclastic lags, reworked sediment and ferruginous mineralisation surfaces (Fürsich et al., 1992). The ferric oxides are responsible for the red colour, as coatings on various allochems and as impregnation in pores of bioclasts (Herbig and Buggish, 1984). The key physical factor for ferruginous coating genesis is a sediment starved well-oxygenated marine environment (Burkhalter, 1995). The strong bimodality of the current roses indicates a current system that periodically reversed direction of flow. The best known example of such periodic current reversal is that of tidal currents (Rossie et al., 2016). The sediments are similar to the cross-laminated bioclastic packstones and grainstones of facies $C$ of Burchette and Wright (1992) and facies belt 6 of Schlager (2005). In the Ramp Microfacies classification of Flügel (2004) FT5 is part of the carbonate sand shoals and banks of inner ramp setting, characterised by accumulations of ooids, skeletal grains and peloids. The sediments resemble RMF27, with medium-coarse grained bioclastic grainstones and a few dominant skeletal types (e.g. echinoderms).

\section{Facies type 3: sandstones}

Description: Sandstone intervals of facies type 3 (FT3) occur in the carbonates of the Molino Limestone. In the SE and SW parts of the study area the Molino Limestone is very sandy and has a patchy distribution pattern. In the field a lateral change can be observed between the sandy grainstones and the sandstones (sections PIE, P, S and R). Sandstone successions are intercalated within the sandy grainstones of FT2b (section $\mathrm{O}$ near Olleros de Alba), and $500 \mathrm{~m} \mathrm{~W}$ of type section $\mathrm{H}$, on the west side of the Bernesga valley, the Molino Limestone is entirely replaced by sandstones of the Gordón Member. In the northern sections $B$ and VG, near Beberino and Vega de Gordón sandstone 


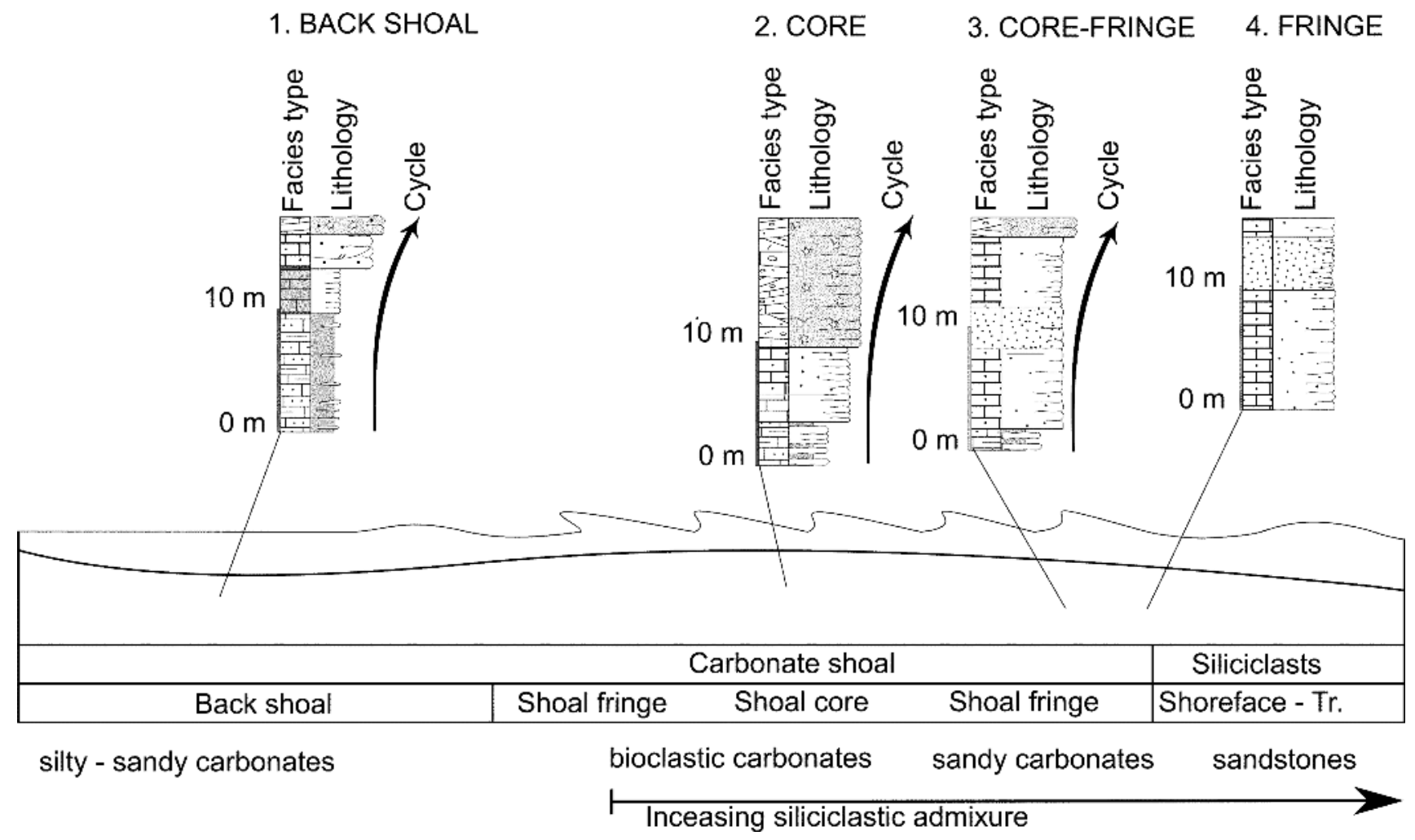

Figure 10. Carbonate facies stacking patterns and cycle types of Molino Limestone. For legend see Figure 5.

Figura 10. Patrón de apilamientos de las facies carbonáticas y tipos de ciclos observados en las Calizas del Molino. Para la leyenda vea la Figura 5.

lenses and layers occur within the coarse grainstones of FT2c. In the Alba syncline the sandstones consist of light yellow and grey coloured very fine to fine grained, well sorted quartz arenites, partly decalcified, with crinoid ossicles, brachiopods and trilobites. The fine quartz grains have a rounded shape; the finer fraction displays a more angular roundness, locally the sandstones display small-scale cross-lamination. The sediments are organised in $10-30 \mathrm{~cm}$ thick beds with sharp bedding surfaces. At Olleros de Alba the ferruginous sandstones display a red-violet colour. Eastward in the Peña Corada unit (section Robledo) yellow-brown coloured, bioturbated, massive bedded, silty, very fine grained quartz sandstones occur lateral to the Molino Limestone.

Interpretation: The well sorted character of the quartz arenites, the roundness of the quartz grains, the almost complete absence of matrix, the smallscale ripples indicate deposition in slightly agitated water above wave base (Nichols, 2009). The silty very fine grained bioturbated massive sandstones were probably deposited in a slightly deeper environment around storm wave base, where bioturbation is very abundant and almost no inorganic primary sedimen- tary structures can be found, as the primary bedding is completely destroyed by deforming bioturbation structures, resulting in homogeneous sediment (Reineck and Singh, 1975: fig. 462; Prothero \& Schwab, 2004; Nichols, 2009). The depositional texture of the quartz arenites of FT3 displays characteristics similar to the sandy grainstones. They were deposited in the shore area of the inner ramp seaward of the shoals, and fall into inner ramp foreshore facies type C of Burchette and Wright (1992). The silty sandstones were deposited in slightly less agitated water.

\section{Facies Model}

The facies types can be arranged in a facies model with three main depositional shoal environments (Fig. 9E):

- Back-shoal environment: FT1

- Characterised by mud-supported and silty deposits representing a protected back shoallagoonal environment eventually with semirestricted conditions. 
van Loevezijn, G.B.S. and Raven, J.G.M., 2017. Frasnian carbonate shoals and sequence... Boletín Geológico y Minero, 128 (4): $931-961$

- Shoal environment: FT2

- Characterised by grain-supported deposits with a variable sand content.

- Fore-shoal environment: FT3

These sediments represent the siliciclastic area seaward of the shoal where there was persistent supply of terrigenous sand.

The facies model represents a mixed siliciclasticcarbonate shoal complex under wave-current action with a mainly siliciclastic belt seaward of the shoal and a protected back shoal area where calcareous mud was deposited.

\section{Facies stacking patterns}

Within the late HST carbonates of the Molino Limestone, facies stacking patterns or small-scale cycle types can be recognised (Figs. 10, 11). These facies arrangements reflect responses of the different environments towards a single sea-level rise and fall. The basic building blocks of the Molino Limestone are between $5 \mathrm{~m}$ and $20 \mathrm{~m}$ thick and reflect small-scale relative changes of sea- level within the third-order cycles. The units have a well-defined internal structure and vertical stacking of facies. These fundamental depositional units of the Molino Limestone are similar to the small-scale cycles of Hofmann and Keller (2005) for the Middle Devonian carbonate platform of Cantabria and the small-scale cycles recognised in the Frasnian of the Holy Cross Mountains in Poland (Vierek, 2014). They are common in the geological record as basic modules of larger-scale cycles of many carbonate platforms (Elrick, 1995; Hofmann and Keller, 2005). Small-scale cycles are characterised by vertical successions of lithofacies types indicating changes in depositional environment - they therefore vary along the carbonate ramp (Fig. 10; Hofmann and Keller, 2005; Zeller et al., 2015). The typical Molino cycle types are described below as idealised types: transitions between them occur.

Back Shoal: This pattern consists of the facies stacking FT1a, FT1b, FT2b and FT2c dominated by FT1a and FT1b. These back shoal facies types are developed in the lower part of the cycle and are overlain by a thin succession of sandy carbonates and/or bioclastic grainstones of FT2b and FT2c, resulting in a coarsening upward succession. Frasnian climate is characterised by extreme greenhouse conditions (Isaacson et al., 2008; Joachimsky et al., 2009; Vleeshouwer et. al., 2014). Greenhouse carbonate ramps are characterised by a very gentle depositional slope and extensive protected shallow marine shelf areas responding to low-amplitude sea level fluctua- tions (Read, 1998). Large parts of the Molino succession consist of protected facies, reflecting the shallow water and widespread low energy settings. These deposits grade into sandy and coarse skeletal grainstones of the medium-high energy shoal facies. Similar coarsening upward cycles were described by Markello and Read (1982) from the Upper Cambrian, Montañez and Read (1992) from the Ordovician, and Buckovi et al. (2005) for the Lias.

Shoal Core: This facies stacking consists of FT1a, FT1b FT2a, FT2b and FT2c. The cycle type displays a coarsening upward succession characterised by a well-developed FT2c succession of coarse bioclastic grainstones in the upper part of the cycle. Back shoal deposits and fine grained shoal fringe sediments are thinly developed or absent. It is the stacking pattern with the best developed and thickest FT2c succession. The upward increase in carbonate content is caused by an increase in bioclastic fragments at the expense of siliciclastic content.

Shoal Core-Fringe: This pattern consists of the facies stacking FT1a, FT2b, FT3 and FT2c. It contains a well-developed sandy grainstone succession (FT2b). In this cycle type the back shoal deposits of FT1 in the basal part of the cycle and the coarse grainstones of FT2c in the top of the cycle are poorly developed. The sandy carbonates (FT2b) form a significant portion, locally grading into sandstones (FT3). The facies stacking represents a coarsening upward succession with higher sand content than the shoal core cycle type representing the transition between shoal core and shoal fringe cycle types.

Shoal Fringe: This pattern consists of the facies stacking comprising FT2b and FT3. The main part of the cycle consists of sandy carbonates (FT2b) grading into sandstones (FT3). Considerable amounts of veryfine to fine grained sand are admixed and locally the limestone interfingers with the sand deposits of the uppermost part of the Gordón Member, giving the Molino Limestone a patchy distribution pattern. The complex interplay of tides, waves and currents influenced the sediment transport in the inner ramp environment and mixed the carbonate sands with the siliciclastic belt as described from recent settings by Testa and Bosence (1998). This resulted in a mixed sandy carbonate zone: the fringe area of the shoal with stacking patterns 3 and 4 is located in between shoal core and sandstone belt and represent a seaward increase of siliciclastics at the expense of carbonates. In the Alba syncline the Molino Limestone is represented by a shoal core in the northeast, a sandstone belt in the southwest and a mixed siliciclasticcarbonate facies zone in between (Fig.12). 

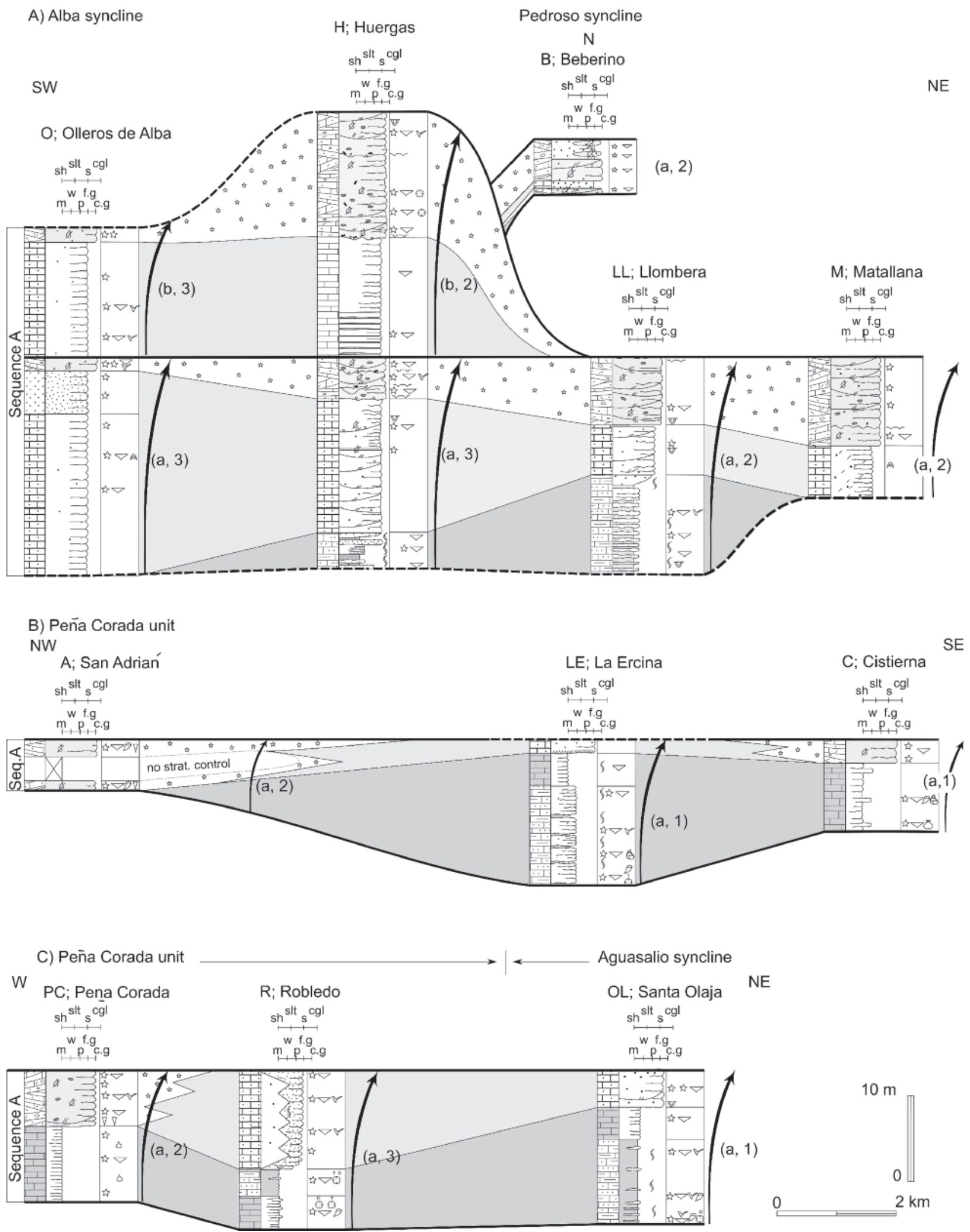

Figure 11. Energy Index correlation of the Molino Limestone grouped by structural unit with the cycle character and cycle type number indicated. Section $O$ is an interpretation after data of Herbig and Buggish (1984). For legend see Figure 5.

Figura 11. Correlación del índice de energía de Calizas del Molino agrupada por unidad estructural, con indicación del carácter y el número de ciclo. La sección O es una interpretación a partir de los datos de Herbig y Buggish (1984). Para la leyenda vea la Figura 5. 


\section{Cycles}

The Molino cycle types are arranged into two cycles, herein called ' $a$ ' and ' $b$ '. Each of the cycles shows an upward increase of depositional energy: cycle ' $a$ ' from mud supported silty sediments (FT1) to sandy and coarse-grained deposits (FT2b and FT2c), and cycle ' $b$ ' from fine-grained and sandy deposits (FT2a and FT2b) to coarse-grained deposits (FT2c). In the correlation chart of Figure 11 for each section the lithofacies types are shown, and for each cycle the level (' $a$ ' or ' $b$ ') and cycle type ( 1 to 4 ) are indicated. The facies types within the cycles were correlated according the interpreted depositional energy: lowenergy muddy deposits of FT1, moderate to highenergy bioclastic and sandy deposits of FT2a, FT2b and FT3, and the high-energy coarse-grained bioclastic sediments of FT2C deposited in agitated water.

Cycle ' $a$ ': Cycle ' $a$ ' is present in all the Molino sections (Fig. 12) and its base forms the lower contact of the Molino Limestone. In the Alba syncline that surface is not exposed. In most sections of the Peña Corada unit the Molino Limestone is underlain by red coloured calcareous, ferruginous, medium grained sandstones, with locally cross-stratified beds. In the easternmost sections $\mathrm{R}$ and $\mathrm{OL}$ the Molino Limestone rests on bioturbated, silty, very fine grained sandstones. Everywhere the surface between the sandstones and the overlying Molino Limestone is a sharp bedding plane. In sections $\mathrm{H}$ and $\mathrm{O}$ the upper boundary of cycle ' $a$ ' is between the coarse bioclastic grainstones of cycle ' $a$ ' and the fine grainstones of the basal part of cycle ' $b$ '. Elsewhere this upper contact forms the upper boundary of the Molino Limestone. In the eastern part of the Alba syncline and in the western part of the Peña Corada unit the cross-laminated grainstones in the top of the Molino succession are overlain by several meters of ferruginous, medium grained cross-stratified sandstones of the Gordón Member. In the easternmost sections of the Peña Corada unit a few meters of bioturbated silty very-fine grained sandstone can be observed above the Molino grainstones. In the Aguasalio syncline, cycle ' $a$ ' is overlain by a dark grey mudstone succession of the Varga Limestone. This makes up the basal part of sequence B (Millar Member), and in the Aguasalio syncline the upper boundary of cycle ' $a$ ' is also the bounding surface between sequences $A$ and $B$ (Fig. 5). In all the above observations the upper boundary of cycle ' $a$ ' is a sharply delineated bedding plane. Internally the cycle shows an upward increase of the depositional energy: from mud supported silty sediments (FT1) to sandy and coarse grained deposits (FT2b and FT2c).

In the northern sections of the Pedroso syncline (B and VG) a thin succession with a Shoal Core cycle type occurs (Fig. 11A). In the central part of the study area the Shoal Core cycle type also dominates (Fig. 12). The Shoal Core area includes the westernmost part of the Peña Corada unit (section A), the eastern part of the Alba syncline (sections LL, M, AV), and the northern sections in the Pedroso syncline (sections VG, B) (Fig. 11A). In the Alba syncline the back shoal facies is represented by silty carbonates (FT1a), grading upwards into sandy grainstone (FT2b). The best developed FT2b succession occurs in the south and is

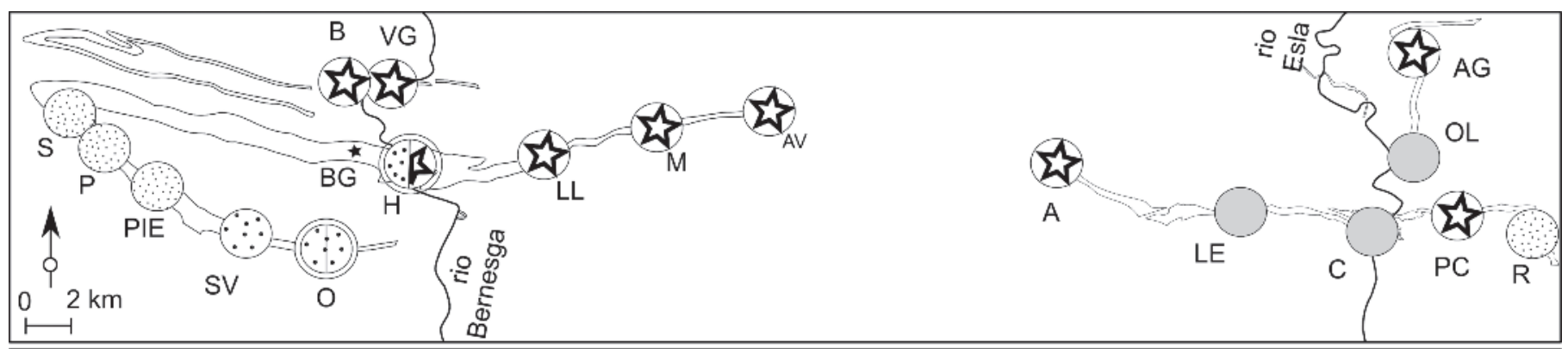

Cycle types 'a'

(3) shoal core

$\because$ shoal core - fringe shoal fringe

back shoal
Cycle types ' $a$ ' and 'b'

shoal core - fringe 'a' shoal core ' $b$ ' shoal core - fringe ' $a$ ' shoal core - fringe ' $b$ '

Figure 12. Distribution of the cycle types of the Molino Limestone.

Figura 12. Distribución de ciclos en las Calizas del Molino. 
very sandy (section Olleros de Alba). The overlying coarse bioclastic grainstones of FT2c are thickly developed in the northeastern part of the Alba syncline. Southwestward of the Shoal Core area the Shoal Core-Fringe cycles occur (sections $\mathrm{H}, \mathrm{O}, \mathrm{SV}$ ). The westernmost sections of the Alba syncline contain a Shoal Fringe cycle type (sections S, P, PIE). The Shoal Fringe sections interfinger with sandstones in the uppermost part of the Gordón Member resulting in a patchy distribution of the limestone indicated by the dashed Molino distribution lines in Figure 1. Eastward of the Shoal Core area, in the Peña Corada unit and the Aguasalio syncline, cycle 'a' occurs in a Back Shoal cycle pattern, with well-developed FT1b (sections LE, C, OL), and in a Shoal Core cycle pattern (sections $\mathrm{PC}, \mathrm{AG}$ ) (Figs. 11B-11C). In the easternmost sections Shoal Fringe cycle types occur (section R), and a lateral change between the Molino shoal sediments and the sandstones of the Gordón Member can be observed.

Cycle' $b^{\prime}:$ This cycle occurs only in part of the Alba syncline within the sections $\mathrm{H}$ and $\mathrm{O}$. The lower boundary is well exposed in both sections; the upper boundary is only exposed in section $\mathrm{H}$. The bounding surfaces are sharp bedding planes with no obvious erosion. Internally the cycle displays a coarsening upward with fine grainstones (FT2a) and sandy grainstones (FT2b) at the base and coarse grained bioclastics in the top (FT2c), representing an upward increase in energy. In section $\mathrm{H}$ the cycle is developed as Shoal Core cycle type with a well-developed FT2c succession. In the south the cycle represents a Shoal Core-Fringe cycle type with more sand - mainly consisting of sandy grainstones.

\section{Depositional model}

During the TST and early HST clastics on the shelf were redistributed and the newly supplied sediment formed the siliciclastic wedge of the Gordón Member. Approaching the maximum flooding stage the sealevel rise slowed, accommodation space gradually decreased, the currents redistributing the siliciclastics were shut off and carbonate content increased, eventually resulting in low net sedimentation with erosion and exposure surfaces. This challenges the reciprocal sedimentation model with the carbonate phase representing high sea-level, and siliciclastic phase low sealevel (Miall, 2016). Dunbar et al. (2000) reported on the results of a core study program along the Great Barrier Reef that in mixed siliciclastic-carbonate environments the maximum rate of siliciclastic sedimentation occurred during transgression, not during the falling stage. They explained this as a result of sediment accumulation and storage on very gentle fluvial slopes across the exposed shelf during sea-level falling and lowstand, and mobilisation and sediment transport by marine processes during subsequent transgressive phases, later termed "transgressive shedding" (Page \& Dickens, 2005). Zeller et al. (2015) used this concept for the mixed siliciclastic-carbonate sedimentation model of the Upper Jurassic to Lower Cretaceous Neuquén Basin in Argentina, requiring marine current systems for the distribution of detrital material. The lateral distribution of clastics on the shelf is related to relative sea-level, as effective sediment transport requires a minimum water depth. During TST and early HST the water depth is sufficient to transport the erosion material of the LST, resulting in predominant siliciclastics. During the late HST siliciclastic distribution on the shelf is reduced substantially due to a lack of siliciclastic input from the largely flooded source area and insufficient accommodation space for currents to develop. Increased carbonate production during the highstand will further reduce accommodation space and thus shut off siliciclastic shelf transport, leading to carbonate dominance and reworking. The Molino deposits of the cycles ' $a$ ' and ' $b$ 'demonstrate an upward decrease of siliciclastic sedimentation, combined with an increase of carbonate sedimentation and a decrease in accommodation space.

\section{Depositional history}

Small changes in relative sea-level generated deepening pulses and created accommodation space for two Molino cycles, ' $a$ ' and ' $b$ ' of which the first has an extensive geographical distribution, and the second only occurs in the Bernesga area (sections Olleros de Alba and Huergas). The facies analysis and correlations of the Molino cycles and additional stratigraphical data of Sanchez de la Torre (1977), Raven (1983), Herbig and Buggish (1984), Loevezijn (1986), and García-López et al. (2002) facilitate the reconstruction of the depositional history of the Molino Limestone. Figure 13 illustrates the proposed depositional model, with the transition from siliciclastic dominance (Fig. 13A) to carbonate dominance (Fig. 13D) as can be observed in the small-scale cycles ' $a$ ' and ' $b$ ' of the Molino Limestone. During the early Frasnian highstand, a progradational siliciclastic coarsening upward sequence developed in the distal parts of the Asturo-Leonese shelf (Raven, 1983; Loevezijn, 1986; Keller et al., 2008). The main source of the siliciclastics was the Asturian geanticline land area in the north. 
van Loevezijn, G.B.S. and Raven, J.G.M., 2017. Frasnian carbonate shoals and sequence... Boletín Geológico y Minero, 128 (4): $931-961$

The grain size varies from clay to coarse sand, locally micro-conglomeratic, requiring subaqueous transport from the hinterland to the shelf (Nichols, 2009): to the NW and NE of the study area the Upper Devonian is developed in a fluvio-marine facies as indicated by the Upper Devonian facies map of Sanchez de la Torre (1977). Locally there is some evidence of fine sediment brought in by wind (Sanchez de la Torre, 1977). During the development of the siliciclastic wedge and the seaward building of the coast, accommodation space gradually decreased, as the rate of sea-level rise slowed in the late highstand. A shallow marine sandy shelf developed where coastparallel currents and tidal currents were still strong enough to redistribute the siliciclastics, and a succession of cross-bedded, well-sorted, and well-rounded quartz arenites was deposited (Loevezijn, 1986). In the outer area crinoids and brachiopods mixed with the quartz arenites (Fig. 13A). Conodont biostratigraphical data indicate that the first calcareous deposits of the Molino Limestone developed in the outer parts of the sandy shelf area (Raven, 1983).

A coast-parallel facies distribution developed with a distal sandstone zone, a mixed carbonate-siliciclastic zone and a proximal protected zone with silty muddy carbonates (Fig. 13B). In the mixed environments of carbonate sands and coast-parallel siliciclastic belts, coast-parallel currents were of prime importance in the reworking and distribution of clastic sediment along the inner ramp, with a minor shoreward wave-tide current responsible for the transport towards the shore (Testa and Bosence, 1998; Zeller et al., 2015). Effective lateral transport of clastics on the shelf is only possible when the water is deep enough for a current system to be established (Zeller et al., 2015), and therefore further decrease in accommodation space restricted the coast-parallel currents and the sand area to the outermost deeper part of the shelf.

On top of the carbonate sands a shallow marine carbonate shoal developed in an agitated water environment, with constantly shifting substrate, where erosion and in-situ reworking by powerful currents, resulted in a condensed, sediment starved, shoal succession (Fig. 13C). The rose diagrams derived from the sandy distal part of the shoal indicate an almost unidirectional current parallel to the shoals, whereas the rose diagrams from the high-energy shoal core show a strongly bimodal pattern resulting from wave and tide currents perpendicular to the shore (Fig. 14A). The Frasnian isopachs and the Molino shoal facies display a correspondence between shoal core area and thin Upper Devonian (Fig. 14A), indicating that the main shoal developed where subsidence was lower. With increased late HST carbonate production the shoal extended into the adjacent areas forming an almost continuous zone on the inner ramp where coarse bioclastic carbonates indicate the shallowest parts of the shoal (Llombera, Matallana, San Adrián, Peña Corada), with adjacent sandy shoal areas parallel to the land mass of the Asturian geanticline, and a seaward siliciclastic belt located in the outer parts of the shelf (Fig. 13D). A small deepening pulse created accommodation space for a second cycle, cycle ' $b$ ', which occurs (or remains) only in the Bernesga area of the sections Huergas and Olleros de Alba. There coarse grained shoal deposits extended over shoal fringe sediments. The Molino cycles demonstrate a shift of the depositional centre towards the southwest (Fig. 14B). A similar lateral shift of maximum deposition is demonstrated in the Frasnian-Famennian sedimentation pattern. The shift may be related to Late Devonian flexural bending of the lithosphere, as indicated by Keller et.al.(2007), with rapid subsidence south of the study area and uplift and erosion of the Asturian geanticline to the north. The extension of the northern uplifted area caused a basinward depocentre shift through time in a south (west) direction. Sedimentation space was very small, and as carbonate production consumed the available accommodation, the Molino coarsening and shallowing upward cycles were forced to extend into the adjacent depositional areas.

One of the best documented examples of shoals connected to old depositional highs occurs in the Triassic Muschelkalk of SW Germany (Aigner et al., 2007). However these shoals represent isolated developments, whereas the Molino shoals indicate a more continuous coast-parallel development between the land of the Asturian geanticline and the distal deeper shelf area.

\section{Discussion}

Cyclicity within mixed siliciclastic-carbonate sequences can be attributed to controlling processes including sea-level fluctuation, climate and current systems, the interplay between these leading to complex heterogeneous siliciclastic-carbonate successions (Zeller et al., 2015).

Climate: Frasnian climate is characterised by extreme greenhouse conditions (Isaacson et al., 2008; Joachimsky et al., 2009; Vleeshouwer et al., 2014), with short cooling pulses during the latest Frasnian (Joachimsky et al., 2009). Greenhouse carbonate ramps are characterised by a very gentle depositional slope, and due to the overall higher sea-level, 


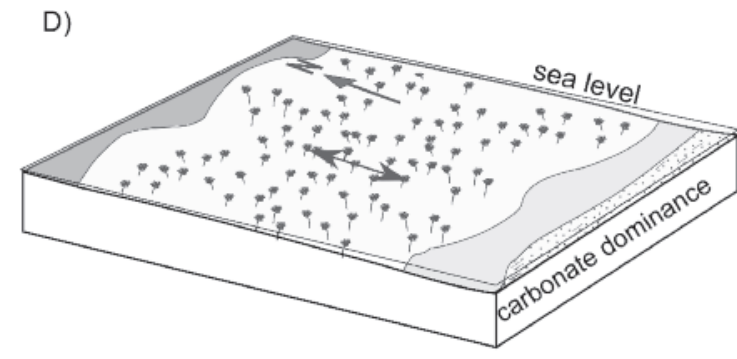

C)

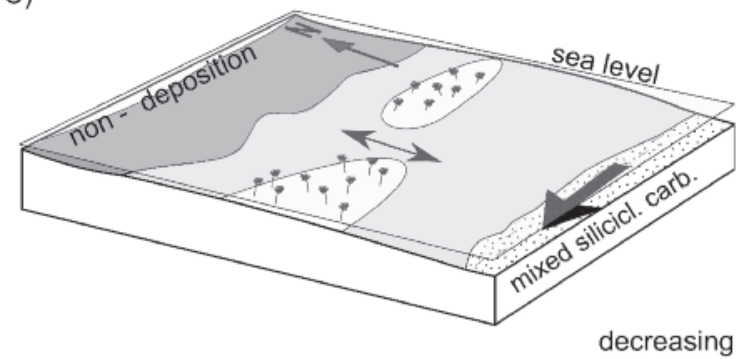

decreasing

B)
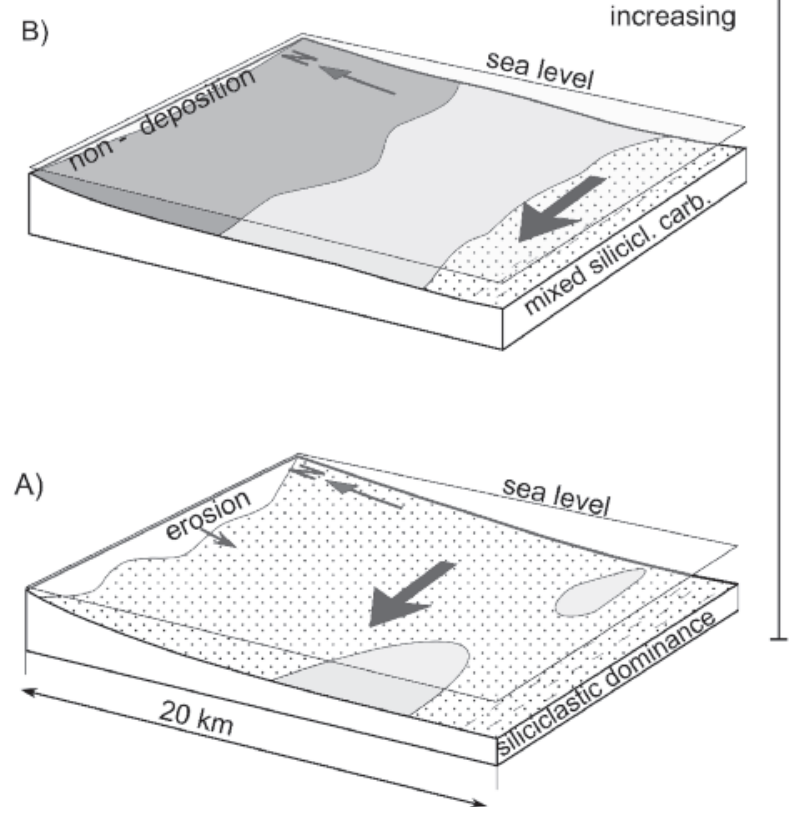

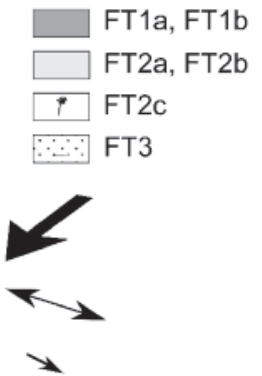

low energy silty carbonate medium energy sandy carbonate high energy coarse biocl. carbonate sandstone

coast-parallel currents

wave - tide currents

detrital input accomodation space

siliciclastic sedimentation

carbonate sedimentation

Figure 13. Summary of the HST with the development from siliciclastic sedimentation to the carbonate sedimentation of the Molino Limestone in 4 steps. (A) Erosion and siliciclastic input from the north, distribution of detrital sediment by coast-parallel currents and small sandy carbonate areas in the distal part of the shelf. (B) Extension of the sandy carbonate sediment area, with a proximal lagoonal belt and a sandy zone seaward of the carbonate sands. (C) Reduction of accommodation space restricts siliciclastic distribution to the distal deeper parts of the shelf where water depth is enough for a coast-parallel current system. On top of the carbonate sands crinoidal shoals occur. (D) Further reduction of accommodation space by highstand carbonate production stops coast-parallel siliciclastic transport and leads to carbonate dominance.

Figura 13. Resumen de HST de la sedimentación de las Calizas del Molino en 4 etapas (A) Erosión y entrada siliciclástica desde el Norte, distribución de sedimentos detríticos por corrientes paralelas a la costa y pequeñas áreas carbonatadas arenosas en la zona distal de la plataforma. (B) Extensión del área de sedimentación de carbonatos arenosos, con un cinturón lagunar proximal y una zona arenosa de arenas carbonatadas hacia el mar. (C) La reducción del espacio de acomodación restringe la distribución siliciclástica a las partes distales más profundas de la plataforma donde la profundidad del agua es suficiente para el desarrollo de un sistema de corriente paralelo a la costa. En la parte superior se generan bancos de carbonatos crinoidales. (D) La reducción adicional del espacio de acomodación debido a la producción de carbonatos detiene el transporte de granos detríticos silíceos paralelo a la costa y fomenta el dominio de los carbonatos. 

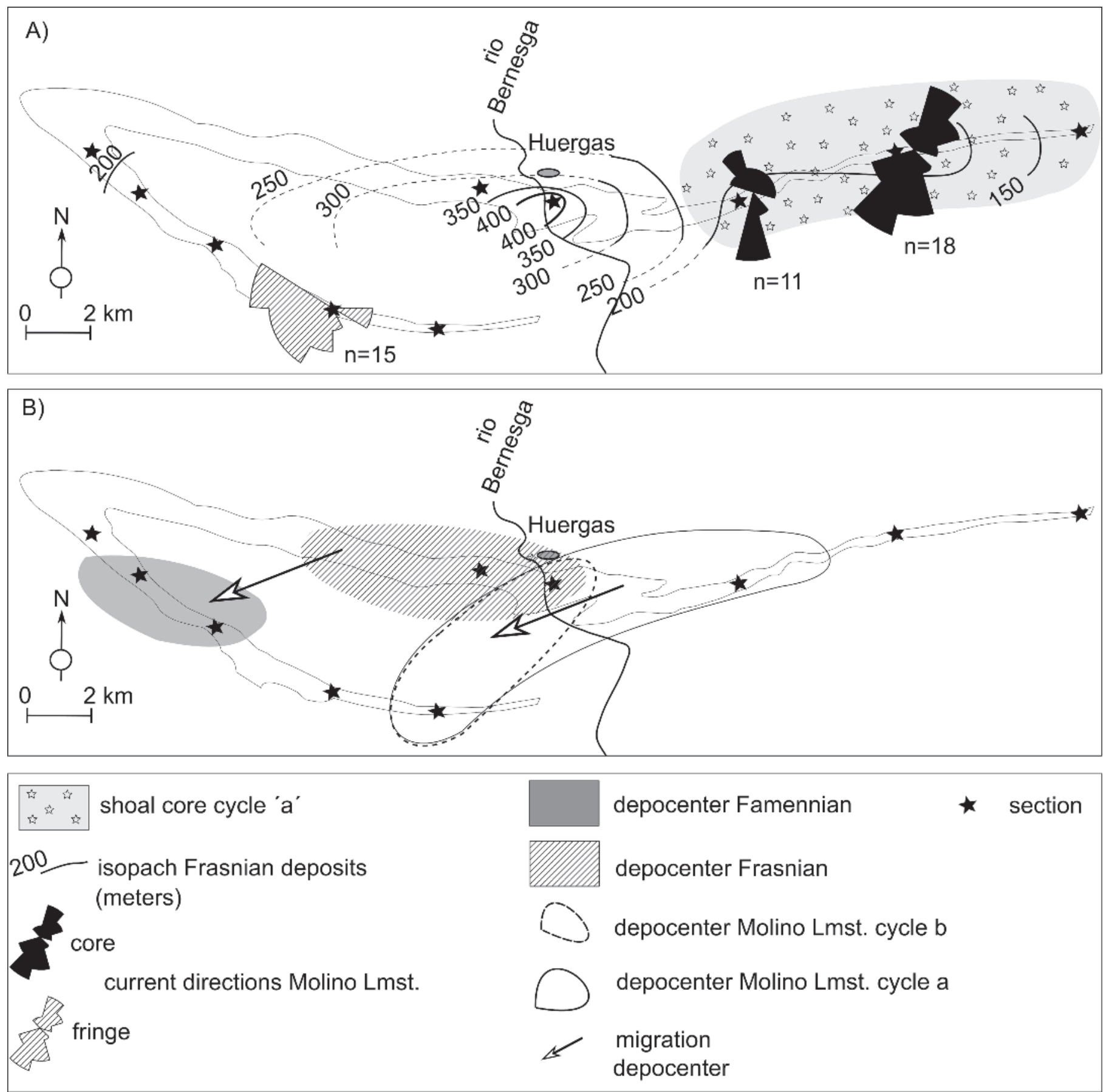

Figure 14. A) Molino Limestone facies map of the Alba syncline, with Frasnian isopachs, cycle ' $a$ ' shoal core deposits, and current directions. B) Upper Devonian depositional trends of the Alba syncline. For legend see Figure 5.

Figura 14. A) Mapa de facies de las Calizas del Molino con isopacas del Frasniense, ciclos de tipo 'a' y direcciones de corriente en el sinclinal de Alba. B) Tendencias sedimentarias del Devónico superior en el sinclinal de Alba. Para la leyenda vea la Figura 5.

shelves will be relatively wide with low-amplitude sea-level fluctuations, and with extensive protected shallow marine shelf areas (Read, 1998; Csato and Catuneanu, 2012). The platform stays relatively shal- low and the sediment production rapidly fills the small amount of accommodation space. The low carbonate sediment productivity of most Palaeozoic carbonate ramps (Elrick and Read, 1991; Schlager, 2005) 
means that optimal situations for ramp development are those in which subsidence is slow (continuous or episodical), and gradients are slight in relatively shallow water. Ramps therefore occur consistently in tectonic regimes characterised by gentle flexural subsidence, such as passive margins and orogenic forelands (Bruchette and Wright, 1992), and are characterized by the development of relatively flat tops which are almost aggraded to sea-level. Gradual subsidence combined with repeated small sea-level changes will be sufficient to generate accommodation space followed by upward shallowing within the shoals as carbonate production rapidly fills the small amount of accommodation space (Read, 1998; Schlager, 2005), thus creating the small-scale cycles of the Molino Limestone.

Carbonate production: The warm climate influences the depth of the photic zone and prevents termination of the carbonate depositional system by siliciclastic input (Buescher, 2003). This is confirmed by our observations in the studied sections; virtually all of the Frasnian siliciclastic sediments contain skeletal components; mainly crinoids and brachiopods, with a varying amount of additional benthos. A common explanation for the carbonate and siliciclastic depositional environments and their variable input is the reciprocal sedimentation model (e.g. Dunbar et al., 2000; Miall, 2016). During relative sea-level lowstand shelf exposure, increasing siliciclastic production and a decrease in carbonate production will occur; during relative high sea-level the flooded areas allow the onset of carbonate production and restrict erosion and siliciclastic input. These alternating sedimentary systems create a clear separation between highstand carbonate cycles and lowstand siliciclastic cycles (Miall, 2016). In the study area the LST is represented by a hiatus - if a siliciclastic wedge developed during this period it would be situated more distally. Siliciclastic deposition in the study area required a higher sea-level. Maybe as result thereof, virtually all of the siliciclastics contain varying amounts of skeletal carbonate components which might indicate a starting up of the carbonate factory. As virtually all of the carbonates contain an admixture of siliciclastic grains, both siliciclastic and carbonate depositional systems co-existed, with sedimentary input of both systems varying in response to sea levels and currents (Table 1).

Currents: Effective lateral transport of clastics on the shelf is only possible when the water depth is enough for a current system to exist. As the water depth decreases the input of siliciclastics will therefore decrease, and carbonate sedimentation will take over. The strength of the currents plays an important role in the siliciclastic distribution on the shelf and is related to sea level (Zeller et al., 2015). In the sequence stratigraphical model of the Frasnian in the study area, siliciclastic sedimentation dominates during TST and early HST, whilst carbonate dominance occurs during late HST (Fig. 7). The higher siliciclastic input during periods of rising and relative high sea level and the late HST carbonate dominance challenges the reciprocal sedimentation model which has siliciclastic deposition during regressive periods and carbonate deposition during transgressive and highstand periods. Dunbar et al., (2000) and Zeller et al. (2015) developed a model for mixed siliciclastic carbonate environments on gently inclined shelf profiles applicable to the Frasnian of the study area. Table 1 summarizes the mixed siliciclastic-carbonate depositional system during global greenhouse times applicable to the Frasnian of the Cantabrian Mountains

\begin{tabular}{|l|l|}
\hline \multicolumn{1}{|c|}{$\begin{array}{c}\text { Siliciclastic and carbonate systems; } \\
\text { Reciprocal sedimentation model }\end{array}$} & \multicolumn{1}{c|}{$\begin{array}{c}\text { Mixed siliciclastic-carbonate systems; } \\
\text { Frasnian Nocedo Formation }\end{array}$} \\
\hline 1. Icehouse climate & Greenhouse climate \\
\hline 2. Rimmed ramp with steep depositional profile & Homoclinal ramp with gentle slope \\
\hline 3. High amplitude relative sea-level fluctuations & Low amplitude relative sea-level fluctuations \\
\hline 4. Sea-level fall can expose entire shelf & $\begin{array}{l}\text { Sea-level fluctuations results in shifting of facies belts on the } \\
\text { shelf }\end{array}$ \\
\hline 5. Periodically complete shut off of carbonate fabric & $\begin{array}{l}\text { Complete shut off of carbonate fabric during sea-level fluctua- } \\
\text { tions unlikely }\end{array}$ \\
\hline 6. Pronounced erosive disconformity bounding surfaces & Less pronounced cycle and sequence bounding surfaces \\
\hline $\begin{array}{l}\text { 7. Clear differentiation into carbonate and siliciclastic depositional } \\
\text { systems }\end{array}$ & $\begin{array}{l}\text { Coexisting mixed siliciclastic-carbonate environments with grad- } \\
\text { ual transitions }\end{array}$ \\
\hline
\end{tabular}

Table 1. Summary of the sedimentation model for the Nocedo Formation versus the reciprocal model.

Tabla 1. Modelo resumido de sedimentación de la Formación Nocedo comparado con el modelo recíproco. 
van Loevezijn, G.B.S. and Raven, J.G.M., 2017. Frasnian carbonate shoals and sequence... Boletín Geológico y Minero, 128 (4): $931-961$

and the separate siliciclastic and carbonate depositional systems during icehouse times of continental glaciations. Our suggested model demonstrates that not only the sedimentary input following the base level concept determines deposition (Pomar, 2001), but that also current systems on gently dipping greenhouse ramps can have a main impact on the depositional mixed carbonate-siliciclastic system.

\section{Conclusions}

The Frasnian Molino Limestone has been studied in eighteen sections in a $70 \mathrm{~km} \mathrm{E-W}$ transect in the southern part of the Cantabrian Mountains. The limestone represents a skeletal carbonate shoal belt in a mixed siliciclastic-carbonate environment, between the land area of the Asturian geanticline and the deeper distal, predominantly siliciclastic shelf.

In this study the organisation of the depositional system within the Molino Limestone is described, a sequence stratigraphic framework is developed, a depositional model is proposed and the evolution of the carbonate shoal is documented.

The Frasnian Nocedo Formation can be sub-divided into two third-order sequences. The first sequence comprising the Gordón Member and the second sequence comprising the Millar Member. The Molino Limestone occurs in the late HST of the first sequence.

The Molino Limestone represents a mixed siliciclastic-carbonate succession of the inner ramp, deposited during greenhouse climate on a gently dipping depositional slope.

Within the Molino Limestone three facies types occur, representing back shoal, shoal, and fore-shoal environments.

The Molino Limestone can be sub-divided into two levels of cycles. These small-scale cycles are of 5-20 m scale and reflect meter-scale relative sea-level changes.

Cycles are arranged into cycle types, which can be classified into Back Shoal, Shoal Core, Shoal CoreFringe, and Shoal Fringe types.

Carbonate deposition is controlled by currents that affect lateral transport of the clastics on the shelf. Currents are related to the water depth facilitating current systems to be established. As the water depth decreases, siliciclastic input will decrease and carbonates will take over. Carbonate production will cause a further reduction of accommodation space which stops siliciclastic coast-parallel transport and leads to carbonate dominance

\section{Acknowledgements}

We would like to thank Dirk van der Marel of the Naturalis Biodiversity Center, Leiden for technical support. Constructive reviews of a previous version of this paper by Amy Nicholson and Agnes van Loevezijn-Peña (Nederlandse Aardolie Maatschappij) and journal reviews by anonymous reviewers and Ana Maria Alonso Zarza are gratefully acknowledged.

\section{References}

Adrichem Boogaerd, H. A. van 1967. Devonian and Lower Carboniferous conodonts of the Cantabrian Mountains (Spain) and their stratigraphic application. Leidse Geologische Mededelingen, 39, 129-192.

Alonso, J. L., A., Marcos, A. and Suárez, A. 2009. Palaeogeographic inversion resulting from large out of sequence breaching thrusts: The León Fault (Cantabrian Zone, NW Iberia). A new picture of the external Variscan Thrust Belt in the Ibero-Armorican Arc. Geologica Acta, 7 (4), 451-473.

Alonso, J. L., Marcos, A. and Pulgar, J. A. 1991. Persistent basement wrenching as controlling mechanism of Variscan thin-skinned thrusting and sedimentation, Cantabrian Mountains, Spain: Comment. Tectonophysics, 194, 171-176.

Aramburu, C., Méndez-Bedia, I., Arbizu, M. and GarcíaLópez S. 2004. La sequential preorogénica. In: Vera, J. A. (ed), Géologia de España. SGE-IGME, Madrid, 27-34.

Arthur, M. A. and Sageman, B. B. 2004. Sea level control on source rock development: perspectives from the Holocene Black Sea, the Mid Cretaceous Western Interior Basin of North America, and the Late Devonian Appalachian Basin. In: Harris, N. B. (ed.), The Deposition of Organic-Carbon-Rich Sediments: Models, Mechanisms, and Consequences. SEPM Special Publication, 82, 35-59.

Brouwer, A. 1964. Deux facies dans le Devonien des Montagnes Cantabriques Meriodionales. Breviora Geologica Asturica, 4, 3-10.

Buckovi , D., Cvetko, T., and Mezga, A. 2005. The origin of coarsening-upward cycle architecture; an example from Middle Liassic platform carbonates of mountain Velika Kapela (Croatia). Geologica Carphatica, 56 (5), 407-414.

Buescher, O. 2003. Facies and Sequence Architecture of Mixed Carbonate-Siliciclastic Depositional Systems during Transforming Sag to Foreland Basin Geometries "Sundance Basin", Middle and Late Jurassic, Western United States. Rheinischen Friedrich-WilmelmsUniversitaet, Bonn, 304 pp.

Burchette, T. P. and Wright, P. 1992. Carbonate ramp depositional systems. Sedimentary Geology, 79, 3-57.

Burkhalter, R. M. 1995. Ooidal ironstones and ferruginous microbiolites: origin and relation to sequence stratigraphy (Aalenian and Bajocian, Swiss Jura mountains). Sedimentology, 42, 57-74. 
Catuneanu, O., Galloway, W. E., Kendall, C. G. St. C., Miall, A. D., Posamentier, H. W. and Strasser, A. 2011. Sequence Stratigraphy: Methodology and Nomenclature. Newsletters on Stratigraphy, 44 (3), 173-245.

Comte, P. 1959. Recherches sur les terrains anciens de la cordillaire Cantabrique. Memorias del Instituto Geológico y Minero de España, 60, 1-440.

Csato, I., Catuneanu, O. 2012. Systems tract successions under variable climatic and tectonic regimes: A quantitative approach. Stratigraphy, 9 (2),109-130.

Dunbar, G. B., Dickens, G. R. 2000. Massive siliciclastic discharge to slopes of the Great Barrier Platform during sea-level transgression; constrains from sediment cores between $15 \mathrm{~S}$ and $16 \mathrm{~S}$ latitude and possible explanations. Sedimentary Geology, 162, 141-158.

Dunham, R. J. 1962. Classification of carbonate rocks according to depositional texture. In: Ham, W. E. (ed.): Classification of carbonate rocks. American Association of Petroleum Geologists, Memoirs, 1, 108-122.

Elrick M. 1995. Cyclostratigraphy of middle Devonian Carbonates of the eastern Great Basin. Journal of Sedimentary Research, 65 (B), 61-79.

Fernández, L. P., Nose, M., Fernández Martines, E. , Méndez Bedia, I., Schröder, St. and Soto, F. 2006. Reefal and mudmound facies development in the Lower Devonian La Vid Group at the Colle outcrops (Léon province, Cantabrian Zone, NW Spain). Facies, 52 (2), 307-327.

Fernández-Martínez, E., Fernández, L. P., Méndez-Bedia, I., Soto, F. and Mistiaen, B. 2010. Earliest Pragian (Early Devonian) corals and stromatoporoids from reefal settings in the Cantabrian Zone (N Spain). Geologica Acta, 8 (3), 301-323.

Ferretti, A. 2005. Ooidal ironstones and laminated ferruginous deposits from the Silurian of the Carnic Alps, Austria. Bolletino della Societá Paleontologica Italiana, 44 (3), 263-278.

Fischer, A. G. 1982. Long term climatic oscillations recorded in the stratigraphy. In: Berger, W. H., Crowell J. C. (eds), Climate in earth history. National Academy of Sciences, Studies in Geophysics, National Academic Press, Washington DC, 97-104.

Flügel, E., 2004. Microfacies of Carbonate Rocks. SpringerVerlag, Berlin-Heidelberg, 1-976.

Fürsichi, F. T., Oschmanni, W., Singh, L. B. and Jaitly, A. K. 1992. Hardgrounds, reworked concretion levels and condensed horizons in the Jurassic of western India: their significance for basin analysis. Journal of the Geological Society, 149, 313-331.

Galli, G. 1985. Depositional environments in the devonian limestone succession of the Cima Ombladet (Camic Alps, Italy). Facies, 12, 97-112.

García Alcalde, J. L. 2012. Prodúctidos Productidina y Strophalosiidina (Brachiópodos Articulados) del Devónoco de la Cordillera Cantábrica ( $\mathrm{N}$ de España). Universidad de Oviedo, Trabajos de Geología, 32, 10-62.

García Alcalde, J. L., Menendez Alvarez, J. R., García-López, S. and Soto, F. (1985): El Devonico Superior y el Carbonifero Inferior del synclinal de Beberino (Pola de Gordón, Leon, NO de Espana). X Congreso Internacional de Estratigrafía y Geología del Carbonifero, Madrid, 375387.

García Alcalde, J. L., Carls, P., Alonso, M. V. P., Sanz López, J., Soto, F., Truyols-Massoni, M. and Valenzuela-Rios, J. I. 2002. Devonian. In: Gibbons, W. and Moreno, T. (eds), The Geology of Spain. The Geological Society, London Bath (UK), 67-93.

García-López, S. 1987. Los conodontos y su aplicación al estudio de las divisiones cronostratigráficas mayores del Devónico Asturleonés (España). Publicaciones Especiales del

Boletín Geológico y Minero de España, 1-112.

García-López, S., Sanz-López, J. 2002. Devonian to Lower Carboniferous conodont biostratigraphy of the Bernesga Valley section (Cantabrian Zone, NW Spain. In: Garcia-Lopez, S. and Bastida, F. (eds), Paleozoic conodonts from northern Spain. Publicaciones del Instituto Geológico y Minero de España (Serie: Cuadernos del Museo Geominero), 1, Madrid, 163-205.

Gharaie, M., Ashouri, A., Khanehbad, M and Ghaderia, A. 2009. Ferruginous oolitic limestone in the Shishtu Formation (Late Devonian) and the role of microbial activities in their formation. Sedimentary Facies, 2 (1), 95-104.

Herbig, H. G. and Buggish, W. 1984. Frasnian limestone intercalations in the Nocedo Formation of $\mathrm{N}$-Leon, Cantabrian Mountains/NW Spain. Zeitschrift der Deutsche Geologische Gesellschaft, 135, 149-161.

Hofmann, M. H., and Keller, M. 2005. Sequence stratigraphy and platform organization of the Devonian Santa Lucia Formation, Cantabrian Mountains, NW-Spain. Facies, 52 (1), 149-167.

Isaacson, P. E., Martinez-Diaz, E., Grader, G. W., Kalvoda, J., Babek, O. and Devuyst, F. X. 2008. Late Devonian- earliest Mississippian glaciation in Gondwanaland and its biogeographic consequences. Palaeogeography, Palaeoclimatology, Palaeoecology, 268 (3-4), 136-142.

Joachimski M. M., Beisig S., Buggish W., Talent J. A., Mawson R., Gereke M., Morrow J. R., Day J. and Weddige, K. 2009. Devonian climate and reef evolution: insides from oxygen isotopes in apatite. Earth and Planetary Science Letters, 284, 599-609.

Julivert, M. 1971. Décollement tectonics in the Hercynian Cordillera of NW Spain. American Journal of Science, 270, 1-29.

Keller, M., Bahlburg, H., Reuther, C. D. and Weh. A. 2007. Flexural to broken foreland basin evolution as a result of Variscan collisional events in northwestern Spain. In: Hatcher, R. D., Carlson, M. P., McBride, J. H. and Catalan M. (eds), 4-D Framework of Continental Crust. Geological Society of America, Memoir, 200, 1-22.

Keller, M., Bahlburg, H. and Reuther, C. D. 2008. The transition from passive to active margin sedimentation in the Cantabrian Mountains, Northern Spain: Devonian or Carboniferous? Tectonophysics, 461, 414-427.

Lane, N. G. 1971. Crinoids and reefs. Proceedings of the North American Paleontologic Convention for 1969, volume 11, part J. Reef organisms through time, 1430-1443. Loevezijn, G. B. S, van 1983. Upper Devonian block move- 
ments and sedimentation in the Asturo -Leonese Basin (Cantabrian Mountains, Spain). Leidse Geologische Mededelingen, 52, 185-192.

Loevezijn, G. B. S. van 1986. Stratigraphy and facies of the Nocedo, Fueyo and Ermita formations (Upper Devonian to lowermost Carboniferous) in Leon, N Spain. Scripta Geologica, 81, 1-116.

Loevezijn, G. B. S. van, Raven J. G. M. and Pol, W. 1986. The Crémenes Limestone, a late Frasnian biostrome in the Cantabrian Mountains (northwestern Spain). Neues Jahrbuch für Geologie und Paläontologie, Monatshefte, 10, 599-612.

Loevezijn, G. B. S. van 1987. Development and termination of carbonate sedimentation on intracratonic late Devonian platforms in the Cantabrian Mountains (Spain). Zeitschrift der Deutsche Geologische Gesellschaft, 138, 197-209.

Loevezijn, G.B.S. van 1989. Extinction patterns for the Middle-Upper Devonian stromatoporoid-coral reefs, a case study from the Cantabrian Mountains. Proceedings Koninklijke Nederlandse Akademie der Wetenschappen, serie $B, 92,61-74$.

Machel, H. G. and Hunter, I. G. 1994. Facies models for Middle to Late Devonian shallow-marine carbonates, with comparison to modern reefs: a guide for facies analysis. Facies, 30, 53-65.

Marriott, S. B., Wright, V. P. 2006. Investigating paleosol completeness and preservation in mid-Paleozoic alluvial paleosoils: A case study in paleosol taphonomy from the Lower Old Red Sandstone. In: Alonso -Zarza A. M., Tanner L. H. (eds), Paleoenvironmental Records and Applications of Calcretes and Palustrine Carbonates. Geological Society of America, Special Paper, 416, 4352.

Miall, A. D. 2016. Stratigraphy - a modern synthesis. Springer, Heidelberg New York Dordrecht London, 457 pp.

Montañez, I. P. and Read J. F. 1992. Eustatic control on dolomitization of cyclic peritidal carbonates: evidence from the early Ordovician Knox Group, Appalachians. Geological Society of America, Bulletin, 104, 872-886.

Markello, J. R. and Read J. F. 1982. Upper Cambrian intrashelf basin, Nolichucky Formation, southwest Virginia Appalachians. American Association Petroleum Geologists, Bulletin, 66, 860-878.

Nichols, G. 2009. Sedimentology and stratigraphy- second edition. Wiley-Blackwell, Chichester (UK), 419 pp.

Nijman, W. and Savage J. F. 1991. Persistent basement wrenching as controlling mechanism of Variscan thinskinned thrusting and sedimentation, Cantabrian Mountains, Spain: Reply, Tectonophysics, 194, 177-182.

Page, M.C. and Dickens, G.R. 2005, Sediment fluxes to Marion Plateau (southern Great Barrier Reef province) over the last $130 \mathrm{ky}$ : new constraints on 'transgressiveshedding' off northeastern Australia. Marine Geology, 219, 27-45.

Pérez Estaun, A., Bastida, F., Alonso, J. L., Marquínez, J., Aller, J., Alvarez-Marrón, J., Marcos, A. and Pulgar, J. A. 1988. A thin skinned tectonic model for an arcuate fold and thrust belt; the Cantabrian Zone (Variscan IberoArmorican Arc). Tectonics, 7 (3), 517-53.

Pérez-Estaun, A., Bea, F., Bastida, F., Marcos, A., MartínezCatalán, J. R., Martínez-Poyatos, D., Arenas, R., Díaz García, F., Azor, A., Simancas, J. F. and Gonzáles Lodeiro, F. 2004. La Cordillera Varisca Europea: EI Macizo Ibérico. In: Vera, J. A. (ed), Geología de España, SGE-IGME, Madrid, 21-25.

Plumley, W. J., Risley, G. A., Gravers, R. W. and Kaley, M. E. 1962. Energy Index for Limestone Interpretation and Classification. In: Ham W. E. (ed.), Classification of carbonate rocks. American Association Petroleum Geologists, Memoir, 1, 85-107.

Pomar, L. 2001. Types of carbonate platforms, a genetic approach. Basin Research, 13, 313-334.

Prothero, D. R. \& Schwab, F. 2004. Sedimentary Geology, an introduction to sedimentary rocks and stratigraphy - second edition. W. H. Freeman and Company, NewYork, 557 pp.

Radig, F. 1962. Ordovicium/Silurium und die Frage pravariszischer Faltungen in Nord Spanien. Geologische Rundschau, 52, 346-457.

Raven, J. G. M. 1980. De bovendevonische afzettingen in het Esla gebied (Cantabrisch Gebergte, Spanje): sedimentatie en tektoniek. Leiden University, Department of Stratigraphy and Palaeontology. Internal Report, 1-72.

Raven, J. G. M. 1983. Conodont biostratigraphy and depositional history of the Middle Devonian to Lower Carboniferous in the Cantabrian Zone (Cantabrian Mountains, Spain). Leidse Geologische Mededelingen, 52, 265-339.

Reineck, H. E., Singh, J. B. 1975. Depoitional sedimentary environments. Springer, Berlin, 439 pp.

Read, J. F. and Horbury A. D. 1993. Eustatic and tectonic controls on porosity evolution beneath sequence bounding unconformities and parasequence bounding disconformities on carbonate platforms. In: Horbury, A. D., Robinson, A. G. (eds), Diagenesis and basin development. American Association of Petroleum Geologists, Studies in Geology, 36, 155-197.

Read, J. F. 1998. Phanerozoic carbonate ramps from greenhouse, transitional and ice-house worlds: clues from field and modelling studies. In: Wright, V.P., BruchetteT. P. (eds), Carbonate ramps. Geological Society London, Special Publication, 149, 107-135.

Remane, A., and Schlieper C. 1971. Biology of brackish Water. John Wiley and Sons, New York, 372 pp.

Rodríguez Fernandez, L. R., García Alcalde, J. L. and Menendez Álvarez, J. R. 1985. La sucesión del Devonico y Carbonifero Inferior en el synclinal de Alba (León, N.O. de España). Comte Rendu, volume 1, X Congreso Internacional de Estratigrafía y Geología del Carbonifero, Madrid, 133-145.

Rossi, V. M., Kim, W., López, J. L., Edmonds, D., Geleynse, N., Olariu, C., Steel, R. J., Hiatt, M. and Passalacqua, P. 2016. Impact of tidal currents on delta cannel deepening, stratigraphic architecture, and sediment bypass beyond the shoreline. Geology, 44 (11), 927-930.

Sanchez de la Torre, L. 1977. Giua de las sessiones de 
campo; Formaciones detriticas y carbonatas del Devonico Medio y Superior de la Cordillera Cantabrica. VIII Congreso Nacional de Sedimentología. OviedoLeón, 1-49.

Sánchez de Posada, L. C., Martinez Chacón, M. L., Villa, E. And Mendez, C. A. 2002. The Carboniferous succession of the Asturian Leonese domain, An overview. In: García Lopez, S. and Bastida, F. (eds), Palaeozoic conodonts of Northern Spain, Publicaciones del Instituto Geológico y Minero de España (Serie: Cuadernos del Museo Geominero), 1, Madrid, 60-91.

Sanz López, J., García Lopez, S. and Montesinos, J.R. 1998. Biostratigraphy and sedimentation of the Vidrieros Formation (middle Famennian-lower Tournesian) in the Gildar-Montó unit (Northwestern Spain). Bolletino della Societá Palaeontologica Italiana, 37, 393-406.

Schlager, W. 2005. Carbonate Sedimentology and Sequence Stratigraphy. Society for Sedimentary Geology, Concepts in Sedimentology and Paleontology, 8, 200 pp.

Testa, V. and Bosence D. W. 1998. Carbonate siliciclastic sedimentation on a high-energy, ocean facing, tropical ramp, NE Brazil. In: Wright, V.P., Bruchette, T. P. (eds), Carbonate ramps. Geological Society London, Special Publication, 149, 55-71.

Truyols, J. Arbizu, M. A., García Alcalde, J. L., García-López, S., Méndez Bedia, I., Soto, F. and Truyols Massoni, M. 1990. Cantabrian and Palencian Zones; Stratigraphy: The Asturian-Leonese Domain (Cantabrian Zone). In: Dallmeyer, R.D. and Martínez García, E. (eds.), PreMesozoic Geology of Iberia. Springer Verlag, Berlin, 10-19.
Vail, P. R., Mitchell, R. M. and Thompson S. 1977. Seismic stratigraphy and global changes of sea level, Part 4Global cycles of relative changes of sea level. American Association of Petroleum Geologists, Memoir, 26, 83-97.

Van Wagoner, J. C., Posamentier, H. W., Mitchum, R. M., Vail, P. R., Sarg, J. F., Loutit, T. S. and Hardenbol, J. 1988. An overview of the fundamentals of sequence stratigraphy and key definitions. SEPM Special Publication, 42, 39-45.

Vierek, A. 2014. Small-scale cyclic deposition in the Frasnian (Upper Devonian) of the Holy Cross Mountains, Poland. Geologos, 20 (4) 239-258.

Vleeshouwer, D., Crucifix, M., Bonceur, N., Claeys, P. 2014. The impact of astronomical forcing on the Late Devonian greenhouse climate. Global and Planetary Change, 120, 65-80.

Westbroek, P. 1964. Systematique et importance stratigraphique des rhynchonelles du Calcaire des Crémenes (Devonien Supérieur, Provence de León, Espagne). Leidse Geologische Mededelingen, 30, 243-252.

Wilson, J. L. 1975 Carbonate facies in geologic history. Springer Verlag, Heidelberg, $471 \mathrm{pp}$.

Yancey, T. E. 1991. Controls on carbonate and siliciclastic sediment deposition on a mixed carbonate siliciclastic shelf (Pennsylvanian Eastern Shelf of north Texas). Kansas Geological Survey, Bulletin, 233, 263-272.

Zeller, M., Verwer, K., Eberli, G. G., Massafero, J. L., Schwartz, E. and Spalletti, L. 2015. Depositional Controls on mixed carbonate-siliciclastic cycles and sequences on gently inclined shelf profiles. Sedimentology, 62, 2009-2037.

Recibido: julio 2016

Revisado: junio 2017

Aceptado: julio 2017

Publicado: diciembre 2017 